\title{
EL BOICOT TURÍSTICO A MÉXICO. CONTROVERSIAS POLÍTICO- DIPLOMÁTICAS A RAÍZ DEL VOTO MEXICANO EN LA RESOLUCIÓN 3379 DE LA ONU
}

\section{Ariela Katz Gugenheim}

Centro de Documentación e Investigación Judio de México

7 ste estudio se centra en una serie de hechos y procesos que tuvieron lugar entre noviembre de 1975 y marzo de 1976; menos de seis meses. Mi propósito es examinar lo que hasta ahora se ha resumido en apenas unas frases, que con pequeñas variaciones dicen: "el 10 de noviembre de 1975, México votó a favor de la Resolución 3379 de la Asamblea General de Naciones Unidas, que definió al sionismo como una forma de racismo. En respuesta al voto, los judíos de Estados Unidos declararon un boicot turístico a México".

Este episodio de la historia mexicana no ha pasado inadvertido pero tampoco ha sido estudiado cabalmente. ${ }^{1} \mathrm{Mi}$ objetivo inicial fue hacer una reconstrucción histórica minuciosa de todo el proceso.

Fecha de recepción: 3 de febrero de 2015

Fecha de aceptación: 2 de septiembre de 2015

1 Bokser Liwerant, “Fuentes” y cimet, “Incomplete”. 
El tema resultó ser mucho más complejo de lo anticipado, y los hallazgos rebasan el límite de lo que es posible exponer en un artículo. Con base en una abundante documentación revisada en archivos gubernamentales e institucionales de México, Estados Unidos e Israel, haré un breve resumen del voto mexicano en la onU, describiré la reacción al voto de México, el boicot turístico que el voto desató y su adopción por el liderazgo judío de Estados Unidos. Haré una síntesis de la reacción del gobierno mexicano al boicot, específicamente en su relación con las comunidades judías mexicana y estadounidense. Por último, relataré la manera en que cesó el boicot. ${ }^{2}$

\section{ANTECEDENTES}

Tras el fracaso por conseguir la expulsión o la suspensión de Israel de la ONU en la década de 1970, ${ }^{3}$ los países árabes se dedicaron a desacreditar al sionismo en ese mismo foro. ${ }^{4}$

En septiembre de 1975 se presentó una oportunidad, cuando comenzaron las reuniones del Tercer Comité de la ONU para cuestiones sociales, humanitarias y culturales. El

2 Para un estudio más extenso y detallado del tema véase Katz, "La Resolución 3379”.

${ }^{3}$ Sadat, el presidente de Egipto, insistió en que era necesario que Israel permaneciera en la ONU para que pudiese exigírsele el cumplimiento de sus resoluciones.

${ }^{4}$ Los estados árabes y africanos, con frecuencia aliados con la URSS, controlaban 101 votos de los 159 que había en la Asamblea General. Por ello, tan solo entre 1970 y 1975, se tomaron más de 30 resoluciones que acusaban a Israel de supuestas prácticas incorrectas o lo ponían bajo investigación, mientras que los asesinatos de once atletas israelíes en las Olimpiadas en Múnich, en 1972, no merecieron ser condenados en la ONU. 
tema era racismo y apartheid y el lanzamiento del programa de la Década contra el Racismo impulsado por la ONU. El 3 de octubre surgió el intento de incorporar dentro de las resoluciones referentes a la Década contra el Racismo una condena al sionismo. ${ }^{5}$ Sin embargo, Estados Unidos y los países europeos habían dejado claro que en ese caso no apoyarían los proyectos. Siendo que para los países africanos era importante que las resoluciones contra el racismo fueran aprobadas por consenso, los estados árabes sugirieron sacar de ellas el tema del sionismo y convertirlo en una propuesta independiente.

Esta iniciativa tomaría como antecedentes la Resolución 3151 de la Asamblea General de la onu (que criticó la “impía alianza" del sionismo con el apartheid), la Conferencia del Año de la Mujer en México (la primera definición del sionismo como una forma de racismo en un foro internacional se llevó a cabo en México, en la Conferencia Internacional del Año de la Mujer), ${ }^{6}$ la Asamblea de Jefes de Estado y de Gobierno de la Organización de la Unidad Africana (ouA) en Kampala, y la Conferencia de Ministros de Relaciones Exteriores de los Países No Alineados en Lima, en 1975, para determinar, con base en ellas, que el sionismo es una forma de racismo y discriminación racial. ${ }^{7}$

\footnotetext{
${ }^{5}$ Véase Manor, To Right a Wrong, pp. 17-20.

${ }^{6}$ Véase Compilación, pp. 12 y 17. Para la descripción de cómo la condena al sionismo fue incorporada a la declaración emanada de la Conferencia del Año de la Mujer véase Katz, "La Resolución 3379”, cap. 1.

7 WiKI, ID: 1975USUNN04923_b Bennett a: Department of State, "Third Committee-Racial Discrimination and Arab Amendments on Zionism”, 10 oct. 1975.
} 
La condena al sionismo en la onu fue votada primero en la Tercera Comisión el 17 de octubre, donde fue adoptada por 70 votos a favor, 29 en contra, 27 abstenciones y 16 delegaciones ausentes.

México votó a favor. ${ }^{8}$

De la Tercera Comisión, la moción pasó a la Asamblea General. Varios comentaron "la ansiedad y el ajetreo inusual” del momento. La sesión extraordinaria duró siete horas. La Asamblea estaba muy tensa, "no por la incertidumbre del resultado, sino más bien por el conocimiento de éste". ${ }^{9}$ Finalmente, la Resolución 3379 fue adoptada por una mayoría de 72 votos a favor, 35 en contra y 32 abstenciones. $^{10}$

Además de Israel, la otra gran perdedora fue la ONU, pues como dijo Sir Brian Urquhart, subsecretario general para Asuntos Políticos Especiales de 1972 a 1986, la Resolución 3379 fue "un pedazo de provocación absurda y contraproducente que produjo un viraje decisivo en los asuntos de Naciones Unidas [...] y sin ayudar de ninguna manera a los palestinos". ${ }^{11}$

México votó a favor "por instrucciones presidenciales". ${ }^{12}$

${ }^{8}$ Véase UNAR United Nations General Assembly, Thirtieth Session, Third Committee, Provisional Summary Record of the Two Thousand One Hundred and Thirty-Third Meeting Held at Headquarters, New York, on Friday, 17 oct. 1975, at 10.30 a.m., pp. 28-29.

${ }^{9}$ Moynihan y Weaver, A Dangerous Place, p. 196.

10 Manor, To Right a Wrong, pp. 51-52.

${ }^{11}$ United Nations Audiovisual Library of International Law http:// legal.un.org/avl/pdf/ls/Urquhart_bio.pdf acceso 15 de octubre de 2013. Schoenberg, The World Conference against Racism, p. 1.

12 Rabasa, Canciller de México, p. 143. 
Los patrocinadores tuvieron la mayoría, pero no contaron con nada parecido al respaldo abrumador que esperaban. Rabasa lo advirtió y escribió que la votación había estado casi empatada. ${ }^{13}$ Este hecho otorga aún más importancia al voto de México.

Algunos investigadores han descrito el voto mexicano como "sorpresivo". ${ }^{14}$ Esta afirmación podría ser adecuada para principios de la década de los setenta, cuando un visitante estadounidense escribió que México es "un país firmemente neutral y se niega a ser arrastrado a cualquier enredo o disputa en el exterior". ${ }^{15}$

Sin embargo, la investigación ha demostrado que para el 10 de noviembre de 1975, prácticamente todos aquellos que habían intervenido activamente en el tema: la Cancillería mexicana, el liderazgo de la comunidad judía de México, el Departamento de Estado de Estados Unidos y el Ministerio de Relaciones Exteriores de Israel, sabían que el proyecto tercermundista de Echeverría, unido a sus aspiraciones personales para cuando terminase su periodo presidencial, habían vuelto imposible que México votara en contra de la resolución, y que aun la abstención era improbable. ${ }^{16}$

Quienes realmente se sorprendieron con el voto de México fueron el público judío de Israel, de México y de Estados Unidos, y la prensa. Es por esto que fueron justamente ellos quienes reaccionaron con asombro, pesar y firmeza, ante el voto mexicano.

\footnotetext{
13 Rabasa, Canciller de México, p. 141.

${ }^{14}$ Véase Bokser Liwerant, "Fuentes", p. 321.

15 Raphael Rothstein, "South of the Rio Grande", The American Zionist (jun. 1971), p. 20.

16 Véase Katz, “La Resolución 3379”, cap. 3.
} 


\section{LA RESPUESTA PÚBLICA AL VOTO}

La reacción judía al voto fue "electrizante”. La delegación de Israel en la onu se vio inundada de telegramas y llamadas, y la embajada de Israel desbordaba de cartas. Los judíos en todos lados ostentaban botones que declaraban "Soy sionista". ${ }^{17}$

Al día siguiente del voto del 10 de noviembre, el Conference of Presidents of Major Jewish Organizations organizó en Manhattan una manifestación masiva en contra del racismo y el antisemitismo. La realidad rebasó todas sus expectativas. Los manifestantes llenaron desde la calle 39 a la 42 y de las avenidas $6^{\mathrm{a}}$ a la $7^{\mathrm{a}}$, y se calculó que asistieron 200000 personas. Aunque la mayoría era de Nueva York, algunos llegaron incluso de Toronto y Atlanta. Los líderes de las comunidades griega, lituana, latina, africana, irlandesa, belga, china, japonesa, polaca, ucraniana, vietnamita, birmana, bielorrusa y serbia, se unieron a la protesta. ${ }^{18}$ Además, hubo manifestaciones para protestar por la resolución en más de 15 ciudades de Estados Unidos. ${ }^{19}$

A los dos días de la votación, Moynihan, el jefe de la delegación de Estados Unidos ante la ONU, apareció en televisión anunciando que los países que habían votado a favor de la resolución sobre el sionismo "sufrirían por ello". Sin embargo, la reacción gubernamental de Estados Unidos fue más bien acorde con lo que ya había declarado Kissinger el 10 de noviembre: "Los Estados Unidos ignoraremos este voto,

17 Herzog, Living History, p. 202.

18 Stern, Anti-Zionism, p. 11 y Troy, Moyniban's Moment, p. 162.

19 Schoenberg, The World Conference against Racism, p. 45. 
no le prestaremos atención, y la Organización de Naciones Unidas se dañará a sí misma si sigue por este camino". ${ }^{20}$

Moynihan trató de entender posteriormente la enorme diferencia entre la reacción gubernamental de Estados Unidos a la Resolución 3379 y la reacción popular. La explicó con base en las actitudes drásticamente diferentes que tenía cada grupo hacia la ONU. Los gobernantes estaban exhaustos y habían perdido interés por lo que transcurría en Naciones Unidas, pero el país todavía tenía mucho interés en lo que estaba sucediendo. ${ }^{21}$

Como lo señaló Moynihan, en toda la historia de Estados Unidos desde que terminó la segunda guerra mundial, no había existido un asunto que lograra tal unanimidad en la opinión pública estadounidense. "Habíamos tocado algo a lo que, a falta de un término más preciso, tendemos a llamar el espíritu nacional”, escribió Moynihan. El país estaba harto de derrotas, de la sensación de que su poder iba disminuyendo. Se sintieron orgullosos de defender sus principios con fuerza y confianza, con asertividad. ${ }^{22}$

Tan sólo en las primeras semanas, la delegación de Estados Unidos en la ONU recibió más de 26000 cartas al respecto. ${ }^{23}$ Los 50 periódicos más importantes de Estados Unidos, sin excepción, condenaron la Resolución 3379, y más de dos terceras partes lo llamaron un acto de antisemitismo. ${ }^{24}$

20 "Questions and Answers Following the Secretary's Pittsburgh Address", 10 nov. 1975, The Department of State Bulletin, vol. LxxiII, núm. 1901, 1 dic., 1975, Washington D.C., p. 766.

${ }^{21}$ Moynihan y Weaver, A Dangerous Place, p. 225.

${ }^{22}$ Moynihan y Weaver, A Dangerous Place, pp. 220 y 224.

${ }^{23}$ Troy, Moynihan's Moment, p. 179.

${ }^{24}$ Stern, Anti-Zionism, p. 12. 
Las reacciones no se dieron únicamente en Estados Unidos. Líderes intelectuales como Jean-Paul Sartre, Pierre Mendes-France, Simone de Beauvoir, François Mitterrand y René Cassin, el jurista francés que ayudó a redactar la Declaración Universal de los Derechos Humanos, calificaron la votación como "una falsificación de la verdad histórica". El ministro de Asuntos Exteriores holandés, Max van der Stoel, dijo que el gobierno holandés no cooperaría con el programa de lucha contra el racismo, en señal de protesta. ${ }^{25}$ Así mismo hubo reacciones de intelectuales y políticos en Londres, Berlín, Ginebra, entre otros. ${ }^{26}$

Todavía recuperándose de la guerra de Yom Kipur de 1973, los israelíes resintieron profundamente la condena. El embajador de Estados Unidos en Israel reportó: "Israel, a menudo dividido y fraccionado, hoy está unido sólidamente". ${ }^{27}$

México, tras su voto a favor de la Resolución 3379 del 10 de noviembre, no hizo ninguna aclaración o comentario oficial. Sin embargo, como escribió Rabasa años después, "el voto mexicano en Naciones Unidas sobre el sionismo tuvo importantes resonancias dentro y fuera del país". ${ }^{28}$

Poco después del voto, Echeverría dio una conferencia de prensa acerca de la política internacional de México. En ella,

\footnotetext{
25 STERn, Anti-Zionism, p. 177.

26 “The Enlightened World Reacts”, Israel Digest, pp. 3-4. Cabe mencionar que tres días después de la votación, una bomba explotó junto al café Naveh, en la calle Jaffa, en Jerusalén, al lado de un área peatonal. Siete personas murieron y 45 resultaron heridas. Un portavoz de la olP declaró que se había confirmado la legalidad de la lucha armada para combatir la dominación.

27 WiKI, ID: 1975TELAV07133_b, Toon, “Israel Rejects UN Resolutions on Zionism and the Palestinians”, 11 nov. 1975.

28 Rabasa, Canciller de México, p. 144.
} 
proclamó que "el récord" de México estaba claro: "México no es antisemita, de hecho, los judíos siempre han vivido aquí en paz”. Pero después agregó: "Lo que Israel tiene que dejar claro es que sionismo no es expansionismo dirigido contra sus vecinos. Cuando se haga esto, el Gobierno modificará su actitud en el tema". ${ }^{29}$ Estas declaraciones no aminoraron el efecto negativo del voto de México.

Posteriormente Echeverría habría de reconocer que la intención de la Resolución era perjudicar a Israel, pues: "Entre esos 72 votos hay algunos [...] que quieren ver a Israel destruido de una u otra forma", pero agregaría que "México no es uno de ellos". ${ }^{30}$

Justamente por eso, The New York Times escribió que todos sabían cuál sería el voto árabe y soviético, y que tampoco tenían grandes esperanzas de los gobiernos de India y Brasil, o de las "otras naciones tercermundistas que llaman a otros 'racistas', mientras que ellas lo practican en su propio país”. Y sin embargo, afirmó, “el mundo sí esperaba más de Japón y de México". ${ }^{31}$

En el mismo tenor, un ciudadano de Estados Unidos escribió al presidente de México señalando que Japón se abstuvo, a pesar de depender del petróleo árabe en $90 \%$. Afirmó que había contado por lo menos con una abstención por parte

29 WiKI, ID: 1975MEXICO10319_b, Calderhead, "Echeverria's Press Conference on Foreign, Policy Matters", 24 nov. 1975.

30 YUA-IM, c. 15, fol. 4, "Transcript Mexico meeting, December 12, 1975”, “Audiencia con el Presidente de México, Sr. Luis Echeverría, otorgada a los presidentes de grupos judíos de los Estados Unidos Americanos", parte 5, p. 3.

31 "Shame of the U.n.", New York Times (13 nov. 1975). 
de México. ${ }^{32}$ Claramente éste era un sentir compartido, pues al día siguiente de la votación, durante la manifestación que tuvo lugar en Nueva York, había pancartas que decían: "Brasil, apestas, ¡y tú también México!". ${ }^{33}$

En México, la reacción no fue inmediata. Tomó más de diez días para que el Comité Central Israelita de México colocara un anuncio en el que se defendía al sionismo. Lo publicó en ocho diarios editados en la Ciudad de México (pero no en El Nacional, propiedad del gobierno). ${ }^{34}$ Sergio Nudelstejer, presidente interino del Comité Central y representante en México del American Jewish Committee, escribió: "Este documento es la primera respuesta oficial de la comunidad judía mexicana al gobierno de este país" ${ }^{35}$

Mientras que los judíos de Estados Unidos, al día siguiente de la votación, inundaron el Garment District de Manhattan con su protesta, los judíos de México tardaron casi dos semanas en asumir una postura pública.

Es cierto que las actitudes de uno y otro país a ese respecto fueron antagónicas. Debe haberle tomado tiempo y esfuerzo a la representación oficial de los judíos en México encontrar una fórmula mediante la cual pudiera protestar por el voto sin expresar al mismo tiempo una crítica al gobierno. Evidentemente, el liderazgo de la comunidad judía

32 AHSRE VIII/411.11(XXX)(08)/68. L-2262 Sardinero. Carta de Oscar Harris, 28 nov. 1975.

${ }^{33}$ John F. Burns, "Huge Rally Here Condemns U.N. Anti-Zionism Move”, The New York Times (12 nov. 1975), “The Week in Review”, p. 89. ${ }^{34}$ NSA, Cable MEXICO 10350, Calderhead, "Visit with president Echeverría's emissary, Fernando Gutierrez Barrios”, 25 nov. 1975.

35 AJC, Foreign Affairs Department, c. \# 33, carp. Mexico 1975-1976, Zionism Resolution, Reaction-Boycott, Sergio Nudelstejer a Morris Fine, 24 nov. 1975. 
vio ineludible pronunciarse sobre el tema, y sin embargo, el texto del desplegado demuestra su ambivalencia.

El manifiesto que firmó el Comité Central está escrito en nombre de la comunidad judía mexicana, "integrada por ciudadanos mexicanos, hijos y nietos de hombres que encontraron paz y una vida digna en este país", por lo que podría asumirse que tenían el derecho de expresarse libremente; sin embargo, en aquel desplegado ni siquiera se menciona que México votó a favor de la Resolución 3379, a pesar de que esto era de amplio conocimiento público.

Así como el voto mexicano no fue sorpresivo, la reacción de la comunidad judía de México tampoco lo fue.

De hecho, unos días antes del voto de la Resolución 3379, Nudelstejer escribió que muchas instituciones judías mexicanas habían recibido largos telegramas del World Jewish Congress, de la Jewish Agency, de la World Zionist Organization y de muchas otras entidades, instándolos a hacer declaraciones y manifestaciones en contra del voto mexicano. Y agregó:

El Comité Central Israelita ha considerado que en estos momentos toda manifestación sería muy peligrosa, y así se ha transmitido a las instituciones. Esta reacción [del Comité Central] se debe a que tenemos miedo de que el gobierno, la prensa y la opinión pública de México podría actuar muy drásticamente contra cualquier manifestación que pudiera ser interpretada como una interferencia en la situación política del gobierno mexicano. Hasta ahora la comunidad ha tenido disciplina. ${ }^{36}$

${ }^{36}$ AJC, Foreign Affairs Department, c. \# 4, carp. Zionism Resolution, Reaction-Boycott Carta de Sergio Nudelstejer a Morris Fine, 6 nov. 1975, p. 2. 


\section{EL BOICOT}

La reacción más importante al voto que México emitió a favor de la Resolución 3379 en la ONU fue el boicot turístico implementado por los judíos estadounidenses.

En 1975, el año que nos ocupa, Israel sufría las consecuencias del boicot árabe, que lo aislaba de la comunidad económica internacional. Una revisión somera de los archivos de las organizaciones judías estadounidenses en 1975 revela la enorme preocupación que había a causa del boicot árabe y la gran cantidad de recursos humanos desplegada para tratar de combatirlo. ${ }^{37}$ También muestra que, de cierta forma, la posibilidad de un boicot como medio efectivo de lucha "estaba en el aire".

En cuanto al turismo hacia México, aun antes del boicot judío, estaba en riesgo debido a las acciones del presidente Echeverría. En un acta del Comité Central Israelita de México, ya desde el 18 de septiembre de 1975, los líderes judíos mexicanos expresaron su temor de que el comportamiento del gobierno de México [en este caso en referencia a la apertura de una oficina de la Organización para la Liberación de Palestina (OLP) en el país] pudiera afectar al turismo proveniente de Estados Unidos. ${ }^{38}$

Tan solo se necesitaba un activismo judío estadounidense fuerte y comprometido, y éste ya parecía estar listo. Durante las semanas anteriores a la guerra de los Seis Días, en 1967, hubo temores de "un segundo Holocausto". Cuando la amenaza de exterminio fue seguida por la victoria relámpago

37 Archivos del AJC, Archivos de Hadassah, Archivos del Presidents' Conference entre otros.

38 Bokser Liwerant, "Fuentes”, p. 329. Apud Acta Comité Central del 18 de septiembre de 1975 . 
contra tres ejércitos árabes y la captura de Jerusalén, Israel se transformó en el centro de las actividades de la comunidad judía de Estados Unidos. En 1973, el ataque sorpresivo de Egipto y Siria contra Israel en Yom Kipur fue traumático, y esto acentuó todavía más la importancia que la diáspora judía otorgó a Israel. Cerciorarse de la seguridad del Estado judío y lograr su aceptación dentro de la arena internacional se volvieron los temas principales de su quehacer. ${ }^{39}$

De manera que el voto contra el sionismo en la ONU tuvo lugar justo en la etapa del mayor activismo judío estadounidense, de verdadera efervescencia, cuando el sentir general era el de estar luchando por la supervivencia del Estado judío.

Tras la reacción pública a la Resolución 3379, Henry Kissinger declaró: "Vamos a tener que considerar los votos de forma individual antes de decidir qué acciones específicas tomaremos hacia varios países", ${ }^{40}$ implicando que podría haber represalias. Éstas nunca se materializaron, pero dicha declaración pudo haber sentado un ambiente favorable para que los judíos de Estados Unidos las implementaran, sabiendo de antemano que sus acciones estaban acordes con los propósitos de su gobierno. Cabe destacar que los judíos estadounidenses percibieron la Resolución 3379 no solo como antiisraelí y antisemita sino también como antiestadounidense. ${ }^{41}$

Desde que se dio el voto de México a favor de la condena al sionismo en la Tercera Comisión, el 17 de octubre de 1975, llegaron cartas a la Presidencia mexicana en que protestaban

\footnotetext{
39 Raffel, Jerwish Polity and American Civil Society, p. 104.

40 Bernard Gwertzman, "Kissinger warns of haste on U.N.", The New York Times (12 nov. 1975), p. 11.

${ }^{41}$ Charles A. Krause, "Jews Shun Countries for Anti-Zionist Vote", The Washington Post (6 dic. 1975), sec. A, p. 12.
} 
por el comportamiento de México y avisaban de un boicot aún incipiente. ${ }^{42}$

Ya mencioné la movilización popular estadounidense ante el voto de la Asamblea General, que culminó con un multitudinario mitin en Nueva York y otras ciudades. Estas manifestaciones no satisficieron la indignación sino que, al contrario, la enardecieron y fueron seguidas por numerosas cartas de protesta enviadas de manera personal a las representaciones de México en Estados Unidos y al presidente Echeverría directamente. ${ }^{43}$

Las misivas protestaban por el voto de México y expresaban su disgusto señalando que cancelarían sus planes para viajar a este país. La mayoría lamentaba que México, país al que los unían lazos de amistad y cariño, hubiera votado de esa manera.

La cantidad de cartas que se distribuyeron para firma fue mínima. La mayoría son manuscritas, enviadas por hombres y mujeres adultos, pero las hay incluso de niños menores de 12 años. Hay textos enojados, tristes, agresivos e incluso suplicantes, tan diversos como las personas que las escribieron. Muchos son de los grandes centros de población, con comunidades judías fuertes, como Nueva York y Los Ángeles, aunque también los hay de Detroit, Dallas, Chicago, Indianápolis, Belmont, Newport y muchas ciudades más.

${ }^{42}$ En el expediente SPR-824-3 del AHSRE hay muchas cartas que hablan de un boicot a raíz del voto del 17 de octubre. En especial vale la pena mencionar un recorte de periódico que desafortunadamente no tiene fecha pero que sabemos es anterior al 7 de noviembre (fecha en que se le envía a Rabasa) donde se exhorta a boicotear a México.

43 AHSRE, L-2265 NC Sardinero, VIII/411.11 (XXX) (06)/68 Primera y Segunda Parte. 
Cabe mencionar que no todas las cartas son de judíos. Hay también de estadounidenses no judíos, y de mexicanoestadounidenses, que se dicen avergonzados de su país por el voto ante la ONu. ${ }^{44}$

Mucha correspondencia es previa al lanzamiento público del boicot. Con base en ella, y aunado a la documentación interna de las organizaciones judías, podemos afirmar de manera conclusiva que el origen del boicot fue popular y espontáneo. Al principio las cancelaciones se referían a viajes individuales, pero muy pronto comenzaron a abarcar a más gente y a organizar el movimiento colectivo. ${ }^{45}$

Si bien la situación empezaba a alarmar a la Secretaría de Relaciones Exteriores, ésta se habría de agudizar con la proclamación pública del boicot, que tuvo lugar el 23 de noviembre de 1975, cuando un grupo de estadounidenses pagó un anuncio en la edición dominical de The Nerw York Times, exhortando a toda la "gente buena" en Estados Unidos a boicotear a México turística y económicamente. Es importante destacar que esta proclama fue firmada por ciudadanos de Estados Unidos a título individual: no los respaldaba ninguna organización.

A escasas dos semanas del lanzamiento público del boicot, los efectos ya se sentían. Geoffrey Weill, director de Thomas Cook en Baltimore, afirmó que tenía cincuenta oficinas

\footnotetext{
${ }^{44}$ AHSRE, L-2265 NC Sardinero, VIII/411.11 (XXX) (06)/68 Primera y Segunda Parte.

45 AHSRE, L-2265 NC Sardinero, VIII/411.11 (XXX) (06)/68 Primera Parte, "[...] hay ahora un movimiento organizado [...] para disuadir a otras personas decentes y con integridad, de no tomar vacaciones alli”". Carta de Amy R. Sims al Consulado de México en Boston, Massachusetts, 11 nov. 1975.
} 
distribuidas en Estados Unidos y todas habían experimentado una fuerte baja en reservaciones para países que votaron a favor de la Resolución 3379. ${ }^{46}$ Más de 100 agentes de viajes del oeste del país anunciaron una campaña para persuadir a sus clientes de que viajaran a países que sí se opusieron a la resolución de la ONU, como Bahamas y Haití. ${ }^{47}$

La ola de cancelaciones no provenía únicamente de judíos: "El mercado judío acaba de alejarse de México. Y no es sólo la gente judía. Estamos recibiendo cancelaciones de gente no judía también”. La New Jersey Bar Association canceló su junta anual en México y otros grupos no judíos anunciaron que estaban considerando la cancelación de viajes "a países donde los judíos no se sentirían cómodos". ${ }^{48}$

El movimiento popular del boicot logró enorme resonancia con mucha rapidez y las principales organizaciones judías estadounidenses comenzaron a ser presionadas por su membresía para que adoptaran formalmente la consigna.

Antes de la guerra de 1967, el activismo pro Israel dependía de la manera en que judíos prominentes y líderes no judíos usaban su influencia personal en los círculos gubernamentales de Washington. Sin embargo, después de 1967 los judíos de Estados Unidos trataron de ejercer influencia por medio de las organizaciones nacionales, que ya contaban con una base significativa de miembros. ${ }^{49}$ De manera que,

${ }^{46}$ Charles A. Krause, "Jews Shun...", The Washington Post (6 dic. 1975), sec. A, p. 12.

${ }^{47}$ Lynn Langway, “Tourism: The Mexican Cancellation”, Newsweek, 86 (22 dic. 1975), p. 56.

${ }^{48}$ Charles A. Krause, "Jews Shun...", The Washington Post (6 dic. 1975), sec. A, p. 12.

49 Raffel, "History of Israel Advocacy", pp. 118-119. 
como reflejo de su afiliación y por convencimiento propio, no tardaron en enarbolar también ellas la bandera del boicot a México.

En efecto, más tarde Richard Maass, presidente del American Jewish Committee (AJC), escribiría al respecto: “El AJC no participó ni sugirió un boicot. [...] American Jewish Congress y varias otras agencias cancelaron sus viajes a México sólo después de que se volvió imposible llevarlos a cabo, debido a la gran cantidad de cancelaciones". ${ }^{50}$

También Seymour Graubard, presidente nacional de la Anti Defamation League del B'nai B'rith, dijo acerca del origen del boicot: "individuos estadounidenses indignados, corporaciones $\mathrm{y}$, a solicitud de sus miembros, organizaciones judías con programas de viajes, comenzaron a cancelar los viajes que tenían programados". ${ }^{51}$ Parece ser que el proceso fue el siguiente: los individuos presionaron a sus organizaciones locales, y éstas a su vez a las organizaciones nacionales. ${ }^{52}$

Para los primeros días de diciembre, después de una reunión del Comité Ejecutivo a la que atendieron treinta personas que votaron de manera unánime, el American Jewish Congress ya había cancelado sus veintidós viajes a México planeados para el invierno de 1975, cada uno con una extensión de dos semanas, lo que implicaba una pérdida de más de 3700 turistas. También B’nai B’rith y el National Council of Jewish Woman cancelaron sus viajes a México.

\footnotetext{
${ }^{50}$ AJC, Bertram Gold Executive Papers, carp. Mexico-Central America, 1976, Carta de Richard Maass a Gerald S. Jeremias, December 6, 1976, p. 1. ${ }^{51}$ Seymour Graubard, "The Mexican Mission”, ADL Bulletin, published by the Anti-defamation League of B'nai B'rith, feb. 1976.

52 "Jewish tourists boycott Mexico", Brazil Herald, (11 dic. 1975).
} 
Estas cancelaciones fueron motivadas inicialmente por miembros aislados de organizaciones específicas; no se trataba aún de la postura oficial de la comunidad judía de Estados Unidos, pero la presión popular por hacerlo no disminuía, y le correspondió al Presidents' Conference of Major American Jewish Organizations asumir el liderazgo.

Este organismo surgió en 1954, cuando Nahum Goldmann, presidente del World Jewish Congress, Abba Eban, embajador de Israel ante la ONU, y Philip Klutznick, presidente del B'nai B'rith, convocaron a una junta a los presidentes de las principales organizaciones judías de Estados Unidos. Estas reuniones evolucionaron hasta convertirse en una estructura organizativa formal. Se acordó entonces que el Presidents' Conference sería el portavoz de la comunidad judía frente al gobierno estadounidense en asuntos relacionados con Israel. ${ }^{53}$ Como muchas organizaciones judías en Estados Unidos, el Presidents' Conference se volvió más fuerte a partir de la Guerra de los Seis Días, cuando surgió una nueva generación de liderazgo judío pro Israel..$^{54}$

En 1975, Rabbi Israel Miller, vicepresidente de la Yeshiva University de Nueva York, dirigía el Presidents' Conference, que incluía a 32 organizaciones judías nacionales ${ }^{55}$ (hoy son más de 50$).{ }^{56}$

El Presidents' Conference debía actuar por consenso, ${ }^{57} \mathrm{y}$ posiblemente eso fue lo que retrasó su adopción formal del

53 Raffel, "History of Israel Advocacy”, p. 114.

54 Beilin, His Brother's Keeper, p. 65.

55 "Mexican boycott back on", The Miami News (16 dic. 1975), primera plana. La lista está en YUA-IM, c. 15, carp. 7.

56 http://www.conferenceofpresidents.org/about/members acceso 2 de febrero de 2015.

57 Raffel, "History of Israel Advocacy”, p. 120. 
boicot. Sin embargo, la participación en el boicot a México cobró tal fuerza de cohesión en la comunidad judía de Estados Unidos que el Presidents' Conference logró el consenso entre todas sus organizaciones, y aún más que eso. Integró temporalmente dentro de su plataforma al American Jewish Committee, que en ese entonces aún no pertenecía al Presidents' Conference y que participó en el grupo temporalmente, tan solo para ser parte del boicot. ${ }^{58}$

La adopción oficial de las acciones concretas hacia México por parte del Presidents' Conference implicó un impulso aún mayor a la lluvia de cancelaciones. Cada vez más convenciones cambiaban de sede, anulando sus reservaciones en México. Unas eran judías, como la Jewish Funeral Directors of America, pero otras no, como la Guardian Life Insurance, una de las compañías de seguros más grandes de Estados Unidos. ${ }^{59}$ Algunas de las convenciones que se suspendieron tan sólo incluían una participación judía minoritaria, pero los organizadores cancelaron por deferencia a los participantes judíos. ${ }^{60}$

En Chicago, fuera de la oficina de Mexicana de Aviación, marchaban manifestantes cargando pancartas con frases como: "Visita los Estados Unidos, NO México"; y "Pueblo mexicano Sí, gobierno mexicano NO". ${ }^{61}$

58 Ariela Katz Gugenheim. Entrevista con Malcolm Hoenlein, vicepresidente ejecutivo del President's Conference, 10 de enero de 2012.

59 Lynn Langway, “Tourism: The Mexican Cancellation”, Newsweek, 86 (22 dic. 1975), p. 56.

60 "Anti-Zionist vote in UN draws reprisals by private US groups. Jewish boycott cuts deeply into Mexican tourism”, James Nelson Goodsell, The Christian Science Monitor (30 dic. 1975), p. 5.

61 Lynn Langway, “Tourism: The Mexican Cancellation”, Nerwsweek, 86 (22 dic. 1975), p. 56, es una foto. Está también en AHSRE, L-2265 NC Sardinero, VIII/411.11 (XXX) (06)/68 Primera Parte. 
La Union of American Hebrew Congregations anunció que canceló 30 viajes programados para México, ${ }^{62}$ B'nai B'rith canceló $76 .{ }^{63}$ Además distribuyó gratuitamente medio millón de "tarjetas de puntuación" tamaño bolsillo, que de un lado tenían las fechas de los días festivos judíos desde 1975 hasta 1977, y del otro la lista de países que votaron a favor de la Resolución 3379, aquellos que votaron en contra y los que se abstuvieron. Venía impresa la siguiente leyenda: "Guarda esta tarjeta contigo. Te recordará quiénes son tus amigos”. ${ }^{64}$

Esta tarjetita para llevar siempre consigo en la cartera, que detallaba cada uno de los países miembros de la ONU y señalaba claramente cuál fue su postura en la votación, demuestra que el reclamo no era exclusivo hacia México. De hecho, la Union of American Hebrew Congregations anunció la cancelación de cinco viajes a Turquía a raíz de su voto, y el B'nai B'rith también canceló viajes a Brasil por la misma razón. ${ }^{65}$ Sabemos asimismo que en algún momento las organizaciones judías consideraron boicotear también a Granada, en el Caribe, pero por algún motivo el boicot no funcionó. ${ }^{66}$

62 "Protest Actions Continue against US Resolution", The Jewish Herald-Voice (20 nov. 1975), Houston, Texas, p. 4. También en AHSRE, L-2265 NC Sardinero, VIII/411.11 (XXX) (06)/68 Primera Parte.

${ }^{63}$ Lynn Langway, “Tourism: The Mexican Cancellation”, Newsweek, 86 (22 dic. 1975), p. 56.

${ }^{64}$ AJC, "United Nations-Anti-Zionism AJC". Se les llamaba score cards. 65 "Protest Actions Continue against US Resolution", The Jewish Herald-Voice (20 nov. 1975), Houston, Texas, p. 4. Para más acerca del boicot a Brasil, y de la reacción de la comunidad judía brasileña, véase WiKI, ID: 1976BRASIL00756_b, Crimmins, "Continuing Reaction to Brazil's Vote On Zionism”, 28 ene. 1976.

${ }^{66}$ AJC, Bertram Gold Executive Papers, Letter from Richard Maass to Mr. and Mrs. Charles de Gale. 8 dic. 1975, 2 pp. , carp. United Nations, Zionism, dic. 1975. 
Todo parece indicar que los lazos de amistad con México eran genuinos, pues en muchos de los documentos internos quedó expresado el malestar que les causaba implementar el boicot. Sin embargo, es indiscutible que México era el país más cercano, y al que más se viajaba a título personal y como parte de las organizaciones judías. De manera que todas las fuerzas siguieron concentrándose en el boicot a México y la oleada de cancelaciones prosiguió.

\section{LA REACCIÓN DE MÉXICO}

A raíz del boicot turístico, Miguel Alemán, en funciones como presidente del Consejo Nacional de Turismo, invitó a su casa a miembros de la comunidad judía de México para platicar del tema, ${ }^{67}$ y después de ello hizo una gira de bajo perfil por Estados Unidos tratando de reparar el daño causado por el voto.

Se reunió con judíos en la industria de agencias de viajes de Nueva York y del área de Chicago. En Los Ángeles ofreció un desayuno a los doce judíos mayoristas de giras más importantes de California, que representaban una derrama de varios millones de dólares para México al año. ${ }^{68}$

Miguel Alemán también organizó una cena en Los Ángeles para los líderes judíos de las principales organizaciones judías de California. La reservación era inicialmente para 100 personas, pero solo asistieron $24{ }^{69}$

67 CDIJUM, Actas del Comité Central Israelita de México, Número de registro 6501, lib. 12, acta núm. 57, 25 nov. 1975, f. 353.

68 Morris D. Rosemberg, "Mexico...", The Washington Post (28 nov. 1975), Travel, sec. C, p. 4.

${ }^{69}$ Morris D. Rosemberg, "Mexico...", The Washington Post (28 nov. 1975), Travel, sec. C, p. 4. 
La falta de respuesta se debió a que la mayoría de los líderes judíos había percibido la invitación como "un intento por aprovecharse de la comunidad judía”, de manera que pidieron una junta previa con Miguel Alemán. Ahí se le pidió, de manera directa, la explicación oficial acerca del voto mexicano en la ONU.

Alemán respondió que el gobierno había actuado de manera "unilateral", dijo que "El pueblo no había estado involucrado" y que "si lo dejábamos enfriar" las cosas podían ser resueltas con el paso del tiempo. Les aseguró que él mismo "había defendido la causa judía en los círculos internos del gobierno". ${ }^{70}$ Además, les recordó que México abrió sus puertas a "un gran número" de refugiados judíos del nazismo. ${ }^{71}$ Cabe mencionar que tal afirmación no es exacta. ${ }^{72}$ Los líderes judíos le respondieron que si actuaban como les pedía, perderían su credibilidad frente a la comunidad judía estadounidense; al no estar convencidos por sus argumentos, decidieron no asistir a la cena. ${ }^{73}$

Los intentos de reconciliación que realizó Alemán fueron conocidos por las diversas organizaciones judías estadounidenses. ${ }^{74}$ En México se publicó que Alemán había estado

70 Alan Cheuse, "Not Quite at Home. Enigma in Mexico", Present Tense. (Published by the AJC), vol. Three, Number Four, Summer 1976, p. 37. ${ }^{71}$ Morris D. Rosemberg, "Mexico...", The Washington Post (28 nov. 1975), Travel, sec. C, p. 4.

72 Efectivamente hubo cierta inmigración judía a México en la época del nazismo, pero la entrada a México estuvo muy restringida. Véase GLeIZER, El exilio incómodo.

${ }^{73}$ Morris D. Rosemberg, "Mexico...", The Washington Post, (28 nov. 1975), Travel, sec. C, p. 4.

74 AJC, Foreign Affairs Department c. \# 4, carp. Zionism Resolution, Reaction-Boycott, Theodore R. Mann, Chairman, Israel Task Force to NJRAC and CJFWF Member Agencies, p. 2. 
“tres veces en Nueva York dialogando con los representantes de las agencias judías a fin de detener el boicot turístico contra nuestro país, decretado a consecuencia del voto" ${ }^{75}$ Sin embargo, a pesar de su empeño, Alemán no logró persuadirlas. Los líderes judíos interpretaron los esfuerzos de Alemán como expresiones de su interés personal, pues sabían que tenía inversiones en distintos hoteles. ${ }^{76}$

Por su parte, la oleada de cancelaciones no amainaba; era necesario incrementar los esfuerzos por detenerla. Miguel Alemán organizó una cena para los líderes judíos del Presidents' Conference, en Nueva York, ${ }^{77}$ y ahí los invitó a México para discutir el problema con Echeverría. ${ }^{78}$

Las organizaciones judías no estaban seguras de cómo reaccionar ante la invitación que Echeverría - por conducto de Miguel Alemán - les hacía para viajar a México. Temían que rechazarla podría interpretarse como "mala voluntad". Además, la comunidad judía de México, “preocupada por el efecto de tal rechazo, urgía a que se aceptara la invitación”. ${ }^{79}$

Por otro lado, había resistencia a viajar a México sin alguna indicación de que el gobierno estuviera realmente dispuesto a abandonar su postura antisionista. Se decidió que

75 Jorge Avilés Randolph, redactor de El Universal, "no hubo boicot de los judíos contra México”, El Universal (13 dic. 1975), primera plana y p. 6.

76 AJC, Foreign Affairs Department c. \# 4, carp. Zionism Resolution, Reaction-Boycott, Richard Maass, “Observations on Meetings...”, p. 1.

77 Morris D. Rosemberg, "Mexico...", The Washington Post (28 nov. 1975), Travel, sec. C, p. 4.

78 YUA-IM, c. 15, carp. 7, "Report for the Year...", "V. The trouble with Mexico", p. 33.

79 YUA-IM, c. 15, carp. 7, "Report for the Year...", "V. The trouble with Mexico", p. 33. 
aceptarían asistir a dicha reunión, solo después de recibir algún tipo de garantía de que en la junta con Echeverría éste haría declaraciones positivas en referencia al tema sionismoracismo. ${ }^{80}$

LUIS ECHEVERRÍA SE REÚNE CON LOS JUDÍOS DE MÉXICO

Paralelamente a los empeños de Miguel Alemán en Estados Unidos, el presidente Echeverría decidió que había llegado el momento de recibir a los judíos mexicanos, que llevaban pidiendo audiencia con él desde hacía tres meses. ${ }^{81}$

Emilio Rabasa escribió que fue por iniciativa del presidente que se invitó a "prominentes miembros de la comunidad judía mexicana” a un desayuno en Los Pinos. ${ }^{82}$ No menciona que la comunidad judía había solicitado una entrevista desde meses atrás. Es evidente que Echeverría buscaba interlocutores entre los judíos mexicanos que lo ayudaran a lidiar con el problema del boicot de los judíos estadounidenses, y por eso decidió aceptar al fin la audiencia. La reunión fue una consecuencia directa del boicot.

También los judíos mexicanos estaban conscientes de ello, pues Sergio Nudelstejer informó al AJC que Echeverría “finalmente” había aceptado una entrevista con representantes y

${ }^{80}$ YUA-IM, c. 15, carp. 7, “Report for the Year...” "V. The trouble with Mexico”, p. 33.

81 En agosto de 1975, Echeverría anunció que autorizaría la apertura de una oficina de representación de la olP en México. Desde entonces los judíos mexicanos buscaban infructuosamente una audiencia con el Presidente. AJC, Bertram Gold Executive Papers, carp. Mexico-Central America, 1975, Carta de Sergio Nudelstejer a Morris Fine, October 29, 1975, p. 3.

82 Rabasa, Canciller de México, p. 144. 
líderes de la comunidad judía de México, y los había invitado a desayunar a Los Pinos el 27 de noviembre de $1975 .{ }^{83}$

En cuanto la invitación quedó arreglada, Echeverría envió al subsecretario de Gobernación, Fernando Gutiérrez Barrios, a ver al embajador de Estados Unidos en México, Joseph J. Jova, a su casa, con carácter de urgente. El secretario le hizo saber a Jova que Echeverría estaba preocupado por el desgaste de las relaciones entre México y Estados Unidos y quería arreglar la situación. Gutiérrez Barrios aclaró que tanto él como Echeverría reconocían que el deterioro se debía, en gran medida, al proceder de México y que, sin duda, las declaraciones y las acciones del presidente habían jugado un papel sustancial. Afirmó que las relaciones con Estados Unidos eran cruciales para ambas partes, y que Echeverría no quería heredar a su sucesor un problema más, así que estaba dispuesto a hacer lo necesario para "poner las cosas en equilibrio".

Jova respondió que Estados Unidos estaba "dolido y decepcionado" por las declaraciones "más hirientes" de Echeverría y en especial por algunas actitudes y acciones mexicanas en el campo internacional, y mencionó específicamente el tema del sionismo. ${ }^{84}$

Para demostrar que el presidente estaba dispuesto a cambiar de rumbo, el subsecretario le contó a Jova que Echeverría tendría un encuentro con líderes de la comunidad judía el

83 AJC, Foreign Affairs Department, c. \# 33, carp. Mexico 1975-1976, Zionism Resolution, Reaction-Boycott, Sergio Nudelstejer a Morris Fine, "Mexico's vote against Zionism”, 16 dic. 1975, p. 1.

${ }^{84}$ NSA, Cable MEXICO 10288, Jova to Secretary of State, "Visit with president Echeverría’s emissary, Fernando Gutierrez Barrios", Mexico City. 22 nov. 1975, pp. 1-2. 
jueves siguiente. Echeverría quería que Jova estuviera al tanto de que él estaba realizando esfuerzos y "buscando una salida para el dilema antisionista”. Jova agregó en su reporte que había escuchado que tan solo de Estados Unidos ya eran 50 los vuelos chárter cancelados. ${ }^{85}$

Además de Gutiérrez Barrios, la comunidad judía de México también les avisó del desayuno. Nudelstejer visitó la embajada de Estados Unidos y confirmó en estricta confidencialidad que se reunirían hombres de negocios judíos y líderes judíos mexicanos con Echeverría para retomar, en un diálogo privado, sus declaraciones y pensamientos sobre Medio Oriente. ${ }^{86}$

La embajada de Estados Unidos asimismo estaba enterada de la invitación pendiente para los judíos de Estados Unidos. En otro de sus cables a Washington, expresó su opinión acerca de las dos reuniones: si Echeverría se veía con grupos judíos de Estados Unidos y de México, seguramente les

[...] "haría la barba" con el [estilo al] que nos hemos familiarizado tanto en los últimos años, profesando apoyo constante para la supervivencia de Israel, prometiendo plena libertad racial religiosa para los judíos en México, y protestando que la búsqueda de México por una mayor "justicia” económica internacional lo obligó a alinearse con algunos personajes indeseables del tercer mundo en el afán de moderar su comportamiento. ${ }^{87}$

${ }^{85}$ NSA, Cable MEXICO 10288, Jova to Secretary of State, "Visit with president...", Mexico City, 22 nov. 1975, p. 3.

${ }^{86}$ NSA, Cable MEXICO 10350, Calderhead, to Secretary of State "Proposed dialogue on Gom policy towards Zionism”, 25 nov. 1975, pp. 1-2. ${ }^{87}$ NSA, Cable MEXICO 10350, Calderhead to Secretary of State "Proposed...", 25 nov. 1975 , p. 3 . 
Sus palabras se acercaron mucho a la realidad.

En el encuentro, sentados alrededor de la mesa con el presidente estuvieron Sergio Nudelstejer, Simón Feldman, presidente de la Kehilá Ashkenazí de México; el físico judeo mexicano Marcos Moshinsky; Jacobo Zabludovsky, cuyo programa 24 horas era el noticiero más visto del momento; León Davidoff, del Instituto Cultural México Israel, y Gregorio Wallerstein, productor de cine, ${ }^{88}$ entre otros.

Sergio Nudelstejer escribió que el desayuno duró dos horas y cuarenta y cinco minutos, y en él discutieron ampliamente dos "problemas esenciales": la autorización del gobierno mexicano de abrir una oficina de la olp en México y el voto mexicano "en el asunto del sionismo". ${ }^{89}$

Nudelstejer pronunció un discurso frente a Echeverría. En él, puso especial cuidado en subrayar frecuentemente que los judíos en México eran mexicanos: "todos nosotros somos profundamente mexicanos, preocupados y ocupados por los problemas y el destino de la nación mexicana" ${ }^{90} \mathrm{En}$ efecto, en las primeras dos páginas del discurso, lo dice en diversas formas cinco veces.

Tras haber establecido su lealtad a México, el siguiente asunto a tratar fue el de la apertura de una representación de la olp en México, que de hecho era el motivo por el cual habían solicitado audiencia originalmente. Nudelstejer

${ }_{88}$ Rabasa, Canciller de México, p. 144.

89 AJC, Foreign Affairs Department, c. \# 33, carp. Mexico 1975-1976, Zionism Resolution, Reaction-Boycott, Sergio Nudelstejer a Morris Fine, "Mexico's vote against Zionism”, 16 dic. 1975, p. 1.

90 AJC, Bertram Gold Executive Papers, carp. United Nations 1975, Zionism, Mexico "Address by Sergio Nudelstejer at breakfast given by President Luis Echeverría”, 27 nov. 1975. 
expresó que "nuestro país no debe transformarse en una arena de conflictos extranjeros" que no son relevantes para México. Como judíos - agregó- "sentimos que podemos ser blancos fáciles de las calumnias y los ataques de la OLP”, lo que provocaría "tensión, malestar y una atmósfera de fanatismo", por parte de aquellos que "utilizarían la apertura de un país democrático como México para avanzar sus intereses y sus objetivos políticos propios". ${ }^{91}$

El tema de la votación sobre sionismo=racismo fue abordado entonces en tercer lugar, y la manera de presentarlo, así como el contexto del boicot, nos permite adivinar el nerviosismo que debe haberlo rodeado. "Otro asunto que queremos someter a su consideración”, dice Nudelstejer, es "la resolución adoptada en la Asamblea General". Es decir, no menciona el voto de México, sino la resolución tomada por Naciones Unidas.

Nudelstejer explicó qué es el sionismo y habló acerca de su relación íntima con el pueblo judío; por lo tanto, afirmó “sentimos que adoptar la destrucción del sionismo, es lo mismo que adoptar la destrucción del pueblo judío, al que estamos atados por lazos de historia, cultura y tradición”. Más aún, dijo, "Sentimos que la resolución de Naciones Unidas abre la puerta a un nuevo antisemitismo, legitimando el comienzo de una persecución innombrable - apenas tres décadas después del horrible Holocausto de la última Guerra Mundial". ${ }^{92}$

91 AJC, Bertram Gold Executive Papers, carp. United Nations 1975, Zionism, Mexico “Address by Sergio Nudelstejer...”, 27 nov. 1975.

92 AJC, Bertram Gold Executive Papers, carp. United Nations 1975, Zionism, Mexico “Address by Sergio Nudelstejer...”, 27 nov. 1975. 
En referencia a la oficina de la OLP, Echeverría respondió que lo había hecho porque creía que era importante mantener contacto con el grupo de Arafat. La comitiva se quedó con la impresión de que la apertura de esa representación sería pospuesta indefinidamente. ${ }^{93}$

En cuanto a la Resolución 3379 de la onU, Nudelstejer reportó: "entendimos que no era la intención del gobierno acusar a Israel de racista y existe el deseo de rectificación". ${ }^{94}$ Después de la entrevista con el presidente, se tuvo una reunión con el canciller Rabasa, en la cual se acordó que éste viajaría a Israel en una "misión especial". ${ }^{95}$

Unos días después, Echeverría se encontró con Jova. El embajador reportó a Washington que Echeverría se "medio" disculpó por la votación antisionista. Echeverría confesó a Jova que si tuviera que hacerlo de nuevo "tal vez hubiese sido mejor abstenerse"; sin embargo, agregó, por lo menos México había sido consistente con su voto en la Conferencia del Año de la Mujer. ${ }^{96}$ Echeverría le aseguró que pronto habría más votos en la ONU promovidos por la Unión Soviética contra Israel, y que México se abstendría o incluso votaría en contra.

93 AJC, Foreign Affairs Department, c. \# 33, carp. Mexico 1975-1976, Zionism Resolution, Reaction-Boycott, Sergio Nudelstejer a Morris Fine, "Mexico's vote against Zionism”, 16 dic. 1975, p. 1. Estaban equivocados, la oficina sí fue abierta.

94 AJC, Foreign Affairs Department, c. \# 33, carp. Mexico 1975-1976, Zionism Resolution, Reaction-Boycott, Sergio Nudelstejer a Morris Fine, "Mexico's vote...", 16 dic. 1975, p. 1.

95 CDIJUM, Actas del Comité Central, Número de registro 6502, libro 12, acta núm. 355, 25 nov. 1975, f. 353.

${ }^{96}$ NSA, Telegram MEXICO 10689, Jova to Secretary of State Washington. Immediate, Confidential, "Echeverría on the Anti-Zionism Resolution", 5 dic. 1975, pp. 1-2. 
Es importante mencionar que Echeverría no cumpliría lo que dijo a Jova en cuanto a los futuros votos de México, pues tan solo diez días más tarde, y contra el consejo de su Cancillería, México habría de votar de nuevo a favor de resoluciones que implicaban equiparar el sionismo con el racismo.

\section{EL VIAJE DEL CANCILLER EMILIO O. RABASA A ISRAEL}

En el desayuno que tuvieron los judíos mexicanos con Echeverría, surgió la idea del viaje de Rabasa a Israel, para "superar malos entendidos", aprovechando además que en la primera semana de diciembre de 1975 tendría lugar la Conferencia Mundial de Solidaridad Judía en Jerusalén, convocada a raíz del voto de la Resolución 3379 en la ONU, y donde estarían los representantes de las organizaciones judías más importantes de Estados Unidos. ${ }^{97}$ Se consideró que sería provechoso que Rabasa dialogara con los judíos estadounidenses ahí presentes ${ }^{98}$ para superar los "malentendidos" con ellos también.

Rabasa avisó al embajador Jova, "en gran confidencia”, que esa misma noche viajaba a Israel para tratar de arreglar la situación que se había generado por el voto de México sobre el sionismo. "La noticia probablemente saldrá en la prensa mañana”, escribió Jova. El canciller Rabasa confesó a Jova que su misión era una de las más "delicadas y difíciles" que se le habían encomendado, y dijo que en vista de su propia experiencia emocional y familiar, tenía "la intención de hacer todo lo posible para encontrar una solución”. ${ }^{99}$

97 HA, c. 66, carp. Mexico, Mrs. Rose Matzkin, NB 12/18/75.

98 Rabasa, Canciller de México, p. 144.

99 NSA, Telegram, MEXICO10514, Jova to Secretary of State, Immediate, Confidential, "Rabasa visit to Israel”. Mexico City..., 1º dic. 1975. 
En efecto, Rabasa le había contado a Hanan Aynor, el embajador de Israel en México, que para él, el voto de México acerca del sionismo había sido "traumático", pues aunque era un católico devoto, estaba orgulloso de su familia materna, que era judía, y "no quería hacer nada que humillara a los judíos”. ${ }^{100}$ También se lo comentó al embajador de Estados Unidos, a quien le dijo que el voto había sido "emocionalmente agonizante". ${ }^{101}$

Días después, Jova habría de preguntarse retóricamente acerca de la dura tarea del canciller mexicano: ¿quién diseña la política exterior de México, el presidente o el secretario de Relaciones Exteriores? Claramente, se respondía, es el primero, muchas veces reaccionando sin pensar, sin considerar las consecuencias de sus actos y sin aceptar el consejo de sus asesores sobre política exterior. "El pobre canciller Rabasa es entonces asignado a la humillante tarea de recoger las piezas y aguantar las quemaduras de la crítica pública cuando las cosas no marchan bien." 102

En sus memorias, Rabasa se esforzó por aclarar que no viajó a Israel por motivo del boicot turístico sino a "superar malos entendidos". De hecho, a pesar de que en sus memorias sí habla extensamente acerca del voto sionismo=racismo, apenas y dedicó una frase en todo su libro al problema del

100 NSA, Cable 1975MEXICO09440, Brandin to Secretary of State, Priority, Confidential, "Delivery of diplomatic note on Zionism Resolution”, 25 oct. 1975.

101 NSA, Cable 1975MEXICO09858, Jova to Secretary of State, "30th UNGA Anti-Zionism Resolution: Position of Mexico”, 10 nov. 1975, Immediate Confidential.

102 NSA, Cable MEXICO11182, Jova to Secretary of State Washington, "Zionism, racism, and the fundamental dilemma in Mexican foreign policy”, 18 dic. 1975, p. 3. 
boicot. ${ }^{103}$ Sin embargo, es claro que el boicot fue el motivo de la visita de Rabasa a Israel. También sabemos que para el embajador Jova resultaba evidente que el objetivo era detener el boicot a México: "Si la visita de Rabasa logra producir algunos resultados muy visibles [...] tal vez pueda convencer a [...] [la comunidad judía estadounidense] de poner fin a su boicot del turismo a México". ${ }^{104}$

Emilio Rabasa llegó a Israel el 4 de diciembre de 1975, acompañado por el embajador Manuel Tello, director en jefe de la Secretaría de Relaciones Exteriores, y permaneció ahí hasta el día 10 del mismo mes. Rabasa habría de escribir acerca del clima político con el que se enfrentó a su llegada:

La actitud de los israelíes era de sentimiento y reclamación. Entendían el voto durante la Conferencia de la Mujer por tratarse de una reunión celebrada en México y porque la mención del sionismo [...] estaba alojada en apartados específicos. Pero la votación del 10 de noviembre, ya en el seno de Naciones Unidas, era otra cuestión. Se trataba de un ataque frontal y directo. No solicitaban que nos inclinásemos a favor de nadie, simplemente que mantuviésemos una posición neutral. ${ }^{105}$

En la tumba de Teodoro Herzl, en Jerusalém, Rabasa hizo una declaración que llegó a Estados Unidos y a México: “[...] no hay discriminación en Sión y donde no

\footnotetext{
103 Rabasa, Canciller de México, p. 144.

104 NSA, Telegram, MEXICO 10595, Jova to Secretary of State Washington. Confidential, "Mexican Foreign Secretary departs for Israel”, 2 dic. 1975, pp. 1-2.

105 Rabasa, Canciller de México, p. 145.
} 
hay discriminación, no puede existir un Estado racista [...] hemos presenciado tolerancia absoluta en este país" ${ }^{106}$

El canciller Rabasa y el ministro de Relaciones Exteriores, Yigal Alón, sostuvieron varias pláticas. En ellas, Alón declaró que el voto de México fue "particularmente lamentable en vista de la alta estima que Israel atribuye a la posición de México en el mundo, y a la cordialidad que ha caracterizado a las relaciones entre México e Israel”. ${ }^{107}$

Por su parte, Rabasa reiteró al canciller Alón la importancia que México concedía a sus relaciones con Israel, "e hizo hincapié en el deseo de su gobierno de eliminar cualquier malentendido que pudiera haber sido creado como resultado de esa votación". ${ }^{108}$ En efecto, el término de "malentendido" habría de ser el leitmotiv de toda alusión al tema por parte del gobierno mexicano.

Rabasa explicó a Alón que México nunca había sido ni era antisemita, y que veía con agrado a Israel. Que el "voto afirmativo en la ONU llevaba el mensaje de que el gobierno israelí debía acatar las resoluciones de Naciones Unidas [...] [y] que, precisamente para mostrar su buena voluntad, Echeverría había mandado a su secretario de Relaciones Exteriores”. Rabasa también se entrevistó con el primer ministro Yitzjak Rabin, y con el presidente Efraim Katzir. ${ }^{109}$

106 Seymour Graubard, “The Mexican Mission”, ADL Bulletin, Published by the Anti-Difamation League of B'nai B'rith, February, 1976, p. 1 y también en Excelsior (5 dic. 1975), primera plana.

107 Ministry of Foreign Affairs, Israel, Foreign Relations Historical Documents, vol. 3: 1974-1977. Joint Statement Israel-Mexico, 10 dic. 1975.

108 Ministry of Foreign Affairs, Israel, Foreign Relations Historical Documents, vol. 3: 1974-1977. Joint Statement Israel-Mexico, 10 dic. 1975.

109 Ministry of Foreign Affairs, Israel, Foreign Relations Historical Documents, vol. 3: 1974-1977. Joint Statement Israel-Mexico, 10 dic. 1975. 
El gobierno israelí supo apreciar lo importante que era el viaje del canciller mexicano. Efraín Evrón, director general adjunto de la Secretaría de Relaciones Exteriores, escribió un análisis de la visita de Rabasa. Describió la decisión de Echeverría de enviar a Rabasa a Israel, a sostener conversaciones con el gobierno de Israel y con líderes judíos de la diáspora, como "una medida fuera de lo común y altamente significativa". Y agregó: "Para un pueblo orgulloso e impulsivo como el mexicano, esto no tiene precedente". ${ }^{110}$

Rabasa se reunió en Israel con los dirigentes judíos estadounidenses que asistían a la Conferencia Mundial de Solidaridad Judía. ${ }^{111}$ Ahí "las preguntas y comentarios sobre el voto mexicano fueron más difíciles y controvertidos" porque no estaban obligados a mantener ninguna postura diplomática, como fue el caso con Alón durante su reunión. Escribió Rabasa: "todavía hoy ignoro cómo pude, más o menos, salir bien librado". 112

Además de las visitas simbólicas y las declaraciones de amistad, el viaje incluyó intercambios pragmáticos. Quizá el asunto más importante para el gobierno israelí fue el acuerdo respecto a la venta de petróleo mexicano a Israel. ${ }^{113}$

110 ISA, 6732/2 \& Ministerio de Asuntos Exteriores, Oficina del Ministro, E. Evrón, al Vice Primer Ministro y Ministro del Exterior, Jerusalén, 8 dic. 1975 , p. 1.

111 YUA-IM, “Transcript Mexico Meeting...”, 12 dic. 1975, parte 9, pp. 1-2. 112 Rabasa, Canciller de México, p. 146.

113 WiKI, ID: 1975TEHR, N11202_b, Helms citando a Lubrani, embajador extraoficial de Israel en Irán, "Iranian-Israeli Relations”, Secret, 17 nov. 1975. En 1975 solo una pequeña porción del petróleo que adquiría Israel provenía de México, pero el gobierno israelí quería lograr que México doblara o triplicara sus ventas de petróleo a Israel, y el tema se trató con Emilio Rabasa. 
La visita fue muy exitosa, Rabasa había logrado tranquilizar al gobierno israelí, que a su vez trasmitiría a los judíos estadounidenses su beneplácito frente a la futura posición de México en la ONU.

Sin embargo, el incidente más célebre del viaje del canciller Rabasa fue la conmoción causada por la frase que decía que el "malentendido" había sido finalmente "perdonado y olvidado" (forgiven and forgotten).

Por años no parecía fácil determinar el origen exacto de la frase, ni si ésta fue pronunciada por Rabasa. Circularon al respecto múltiples versiones. El tema se aclaró cuando recientemente se publicaron las memorias de Rabasa, quien escribió: “Tampoco pedí perdón [...] La expresión utilizada, forgiven and forgotten, fue totalmente sacada de contexto". ${ }^{114}$

De manera que Rabasa sí dijo las desafortunadas palabras en la comida de despedida. Cabe comentar que a pesar de su excelente inglés, ${ }^{115}$ si esa no era la intención del secretario, se equivocó de expresión. En todo caso, probablemente el faux pas de Rabasa no hubiera tenido tanta repercusión si no hubiera sido por la situación creada como consecuencia de la votación que tuvo lugar en la onu el 15 de diciembre de 1975, que será detallada más adelante y que provocó la ratificación del boicot turístico.

De hecho, antes del voto del 15 de diciembre, concluida la visita de Rabasa a Israel, cuando ya había pronunciado la frase "forgiven and forgotten", Echeverría elogió la visita

114 Rabasa, Canciller de México, p. 148.

115 Ariela Katz Gugenheim. Entrevista con Walter Astié-Burgos, 28 nov. 2011. 
del canciller a Israel, y reconoció que éste había viajado para remediar una situación que era resultado no de las acciones propias sino de las del presidente:

El secretario de Relaciones Exteriores, un oficial joven y entusiasta, fue a Israel $[\ldots]$ Fue a dar una explicación [...]

Y acá en México dicen - los periódicos lo han dicho- que primero el secretario de Relaciones Exteriores hace una cosa en Naciones Unidas, ahora fue a Israel a decir otra cosa. No era él, sino yo, en medio de esta confusión. ${ }^{116}$

El embajador de Estados Unidos en Israel también alabó la labor de Rabasa, pues informó que en los encuentros que tuvo durante su viaje había logrado restablecer relaciones cálidas entre México e Israel. ${ }^{117}$

De manera inmediata, el viaje de Rabasa tuvo un efecto positivo. Como se ha visto, Echeverría había invitado a México a una representación de los judíos de Estados Unidos, pero éstos dudaban en aceptar la invitación del presidente. Antes de decidir, estaban esperando alguna prueba de que efectivamente habría un cambio en la política exterior mexicana. Esta prueba llegó con la declaración de Yigal Alón al término de la visita de Emilio Rabasa.

Alón expresó su satisfacción con la "retractación" de México en el tema de sionismo y racismo, tal y como había sido expresado por el secretario de Relaciones Exteriores. ${ }^{118}$

116 YUA-IM, “Transcript Mexico Meeting...”, 12 dic. 1975, parte 5, pp. 1-2-B 3.

117 NSA, Tel Av 07863, Toon to Secretary of State, Confidential, "Visit of Mexican Foreign Minister Rabasa to Israel”, 12 dic. 1975, p. 1.

118 YUA-IM, c. 15, carp. 5, "Report to the Conference of Presidents of 
Y así se lo comunicó a Israel Miller, el presidente de la Presidents' Conference, asegurándole que Rabasa le había ofrecido una garantía de que "México en el futuro no apoyaría resoluciones antisionistas". ${ }^{119}$

Fue esta declaración, hecha posible por Rabasa, la que permitió que se llevara a cabo el viaje de una delegación de judíos estadounidenses a México, que bien pudo haber resuelto el problema del boicot de manera definitiva.

\section{LA REUNIÓN DE LUIS ECHEVERRÍA CON LOS JUDÍOS DE ESTADOS UNIDOS}

Mientras Rabasa se encontraba en Israel, el 5 de diciembre de 1975, el Tercer Comité de la ONU aprobó la Resolución 2194, que ratificaba la Declaración México completa (incluyendo su condena al sionismo), y la Resolución 2195, que a su vez adoptó por completo, por endoso, la declaración y las resoluciones de la Conferencia del Año de la Mujer y de la Declaración México (incluyendo su condena al sionismo). ${ }^{120}$ México votó a favor en ambas votaciones, sin hacer aclaraciones en la primera, y en la segunda, indicando tan solo que tenía "reservas", pero sin aclarar cuáles eran y sin mencionar el sionismo.

En Estados Unidos, los líderes judíos se decepcionaron por el voto que México emitió el 5 de diciembre, en especial

Major American Jewish Organizations by the Delegation to Mexico", 14 ene. 1976, p. 1.

119 YUA-IM, c. 15, carp. 4, “Transcript Mexico Meeting...”, 12 dic. 1975, part 8, pp. 3-4.

120 AJC, Bertram Gold Executive Papers, carp. United Nations 1975, Zionism, Mexico. 
porque Miguel Alemán les había asegurado que México se disociaría de las partes ofensivas a Israel. ${ }^{121}$

Morton Rosenthal, director de Latin American Affaires de la Anti Difamation League del B'nai B'rith, visitó al Departamento de Estado, mientras esperaba el comunicado oficial de la visita de Rabasa. Les explicó a los funcionarios que Echeverría había invitado a una representación judía estadounidense a viajar a México y comer con él en Los Pinos. Afirmó que temían ser utilizados, por lo que no aceptarían la invitación, a menos que tuvieran evidencias de que habría un verdadero cambio en la política exterior mexicana. ${ }^{122}$

Rose Matzkin, presidenta de Hadassah, reportó a su organización que el martes 9 de diciembre habían llamado para avisarle que el presidente de México estaba dispuesto a hacer una "declaración importante", pero con la condición de que un grupo de líderes judíos viajara a México para el anuncio. ${ }^{123}$

La presión aumentaba, pero todavía no estaban seguros de que fuera conveniente realizar el viaje.

El 10 de diciembre, al escuchar las conclusiones que el ministro de Relaciones Exteriores de Israel pronunció a raíz de la visita del canciller Rabasa, los judíos estadounidenses consideraron que ello era una señal clara y confiable del cambio de actitud por parte de los mexicanos. Las

121 NSA, Telegram STATE 290968, Ingersoll to AMEmbassy. Immediate Confidential "Mexico and the anti-Zionism Resolution", 10 dic. 1975, pp. 1-2.

${ }^{122}$ NSA, Telegram STATE 290968, Ingersoll to AMEmbassy. Immediate Confidential “Mexico...", 10 dic. 1975, pp. 1-2.

123 HA, c. 66, carp. Mexico, Rose E. Matzkin to The National Board, 10 dic. 1975, p. 1. También en Seymour Graubard: "The Mexican Mission”, ADL Bulletin, Published by the Anti-Difamation League of B'nai B'rith, feb. 1976, pp. 1 y 8. 
declaraciones públicas de Rabasa se sumaron a la llamada por parte de Echeverría, y constituyeron así una garantía suficiente de que el gobierno de México ya no apoyaría más medidas antisionistas, por lo que aceptaron la invitación que les hizo el presidente Echeverría. ${ }^{124}$ Es posible que también haya influido que la comunidad judía mexicana les pedía insistentemente que aceptasen la invitación. ${ }^{125}$

Se formó una delegación con 16 personas, en representación de las principales organizaciones judías de Estados Unidos, ${ }^{126}$ y el grupo viajó a México el 11 de diciembre, con los gastos cubiertos por la Presidencia de México. ${ }^{127}$

El gobierno mexicano fue el que lanzó la iniciativa para que se llevara a cabo la reunión, insistió hasta lograrlo y

${ }^{124}$ YUA-IM, c. 15, carp. 5, "Report to the Conference of Presidents...”, 14 ene. 1976, p. 1.

125 YUA-IM, c. 15, carp. 7, "Report for the Year...", "V. The trouble with Mexico", p. 33.

126 YUA-IM, c. 15, carp. 4, copy \#19, “Transcript Mexico Meeting...”, 12 dic. 1975, parte 1, p. 1. También en "Report for the Year...", "V. The trouble with Mexico", c. 15, carp. 7, p. 33. Seymour Graubard, el jefe de la delegación, viajó a México en representación de B’nai B’rith, que en 1975 tenía más de 100000 miembros; Bertram H Gold y Richard Maass viajaron en representación del American Jewish Committee, que derivaba su fuerza "no de los números sino de la calidad y estatus" de sus miembros. Rose Matzkin representaba a Hadassah, la organización sionista femenina de Estados Unidos que en 1975 era la organización sionista más grande del mundo. HA, c. 66, carp. Mexico, "Minutes. Pre-Convention Meetings, National Board of Hadassah, WZOA, Inc., MRA, Inc. 62nd Annual Convention", Washington Hilton Hotel, Washington D.C. Thursday Evening, p. 6, 12 ago. 1976.

127 Para los gastos: "Jewish Congress will resume Mexico boycott", Chicago Tribune (17 dic. 1975), sec. I, p. 5. Para la clase: AJC, Foreign Affairs Department, c. \# 4, carp. Zionism Resolution, Reaction-Boycott, Richard Maass, "Observations on Meetings...”, p. 1. 
realizó la implementación final. Los judíos mexicanos trataron de influir en los líderes estadounidenses para que accedieran a venir, pero aun así, éstos no aceptaron sino hasta que se publicaron las declaraciones de Alón, propiciadas por la visita de Rabasa a Israel.

La documentación revisada muestra que la visita de la delegación de Estados Unidos fue manejada con enorme cuidado por quienes estuvieron involucrados: los miembros mismos de la delegación, el gobierno de México, los judíos mexicanos y la embajada de Estados Unidos en México.

Me parece pertinente mencionar con qué información contaban los judíos estadounidenses en cuanto a la efectividad del boicot turístico a México a su llegada, pues naturalmente este conocimiento marcó la pauta de su visita. Cuando viajaron a México, estaban al tanto de que antes del 10 de noviembre todos los vuelos a México estaban totalmente llenos, y que a partir de esa fecha eran muchos los vuelos casi vacíos. ${ }^{128}$ Además, conocían algunos de los datos que manejaba la Secretaría de Turismo de México: ${ }^{129}$

- Se habían cancelado aproximadamente 30000 viajes turísticos a México.

- Vincent Hodgins, director de la Oficina Mexicana de Turismo en Nueva York, los acompañó en el viaje, y les

${ }^{128}$ El DC10, dependiendo de su configuración, permite entre 250 y 380 pasajeros. Aun en el caso más conservador, se trata de una ocupación de 10\%. http://www.boeing.com/commercial/dc-10/tech.html acceso 9 de diciembre de 2012.

129 AJC, Collection: Foreign Affairs Department, c. \# 4, carp. Zionism Resolution, Reaction-Boycott, Richard Maass, "Observations on Meetings...”, pp. 1-4. 
contó que tan solo en Acapulco se habían cancelado 100000 noches de hotel. ${ }^{130}$

- Sabían que en 1970 el gobierno de México había afirmado que el turismo le producía 2000 millones de dólares anuales, y que $80 \%$ provenía de turistas estadounidenses, y deducían:

Nuestro cálculo es que 50\% de estos dólares de turismo [estadounidense] viene de judíos. Aun asumiendo que no hubo aumento en cinco años, esto significaría 800000 millones de dólares anuales de ingresos a México de parte de los judíos de Estados Unidos, a lo que se agrega el hecho de que gran parte de los mayoristas y operadores turísticos son judíos. Esto da la dimensión del problema que México enfrenta. ${ }^{131}$

Tras llegar a la ciudad de México, la primera reunión que sostuvieron fue con miembros de la comunidad judía en México. En esa reunión, Seymour Graubard, jefe de la delegación, les expuso cuál sería su posición en la reunión con Echeverría y qué le dirían. ${ }^{132}$ Es importante señalar que ésta

${ }^{130}$ Diez millones de dólares de 1975 equivalen aproximadamente a 103 millones de dólares de 2015 calculados como ingresos con poder económico. http://www.measuringworth.com/m/calculators/uscompare/ acceso 2 de julio de 2015.

131 Richard Maass, “Observations on Meetings...”, Foreign Affairs Department, c. \# 4, carp. Zionism Resolution, Reaction-Boycott, pp. 1-4, AJC. Los 800000 millones de dólares de 1975 son casi 8250 millones de dólares de 2015, calculados como ingresos con poder económico. http:// www.measuringworth.com/uscompare/relativevalue.php acceso 2 de julio de 2015. La exactitud de la cifra de 800000 millones de dólares es irrelevante en este contexto. Lo importante es que así lo consideraron. 132 AJC, Foreign Affairs Department, c. \# 4, carp. Zionism Resolution, Reaction-Boycott, Richard Maass, “Observations on Meetings...”, p. 1. 
no fue una junta para pedir consejo acerca de cómo manejar el encuentro, más bien fue una junta informativa para los líderes de la comunidad judeo mexicana.

Según el testimonio de un miembro de la delegación de Estados Unidos, se dio entonces un desencuentro entre los líderes comunitarios de ambos lados del río Bravo:

La reacción fue inesperada. Aunque la comunidad mexicana judía había estado insistiendo durante algún tiempo para que viniera a México una delegación de judíos de Estados Unidos, fue inmediatamente evidente que tenían miedo acerca de la manera en que presentaríamos nuestro caso. Dijeron una y otra vez que no había antisemitismo en México, que Echeverría y Alemán eran sus amigos, y dieron a entender que si ofendíamos al presidente habría una reacción antisemita en el país. ${ }^{133}$

En efecto, los judíos mexicanos les rogaron que expusieran sus puntos de vista "con mucha prudencia y cautela". 134 Es reveladora la preocupación de los judíos mexicanos y es significativo también que fuera tan sorprendente para los judíos de Estados Unidos. Este choque de concepciones obedece a muchos procesos simultáneos: es cierto que los judíos mexicanos habían presionado a los judíos estadounidenses para que aceptaran la invitación de Echeverría y, sin embargo, una vez en suelo mexicano, y habiendo escuchado la asertividad con la que pretendían abordar al presidente, temieron que dicho encuentro alterara el statu quo de su vida en México.

133 AJC, Foreign Affairs Department, c.\# 4, carp. Zionism Resolution, Reaction-Boycott, Richard Maass, “Observations on Meetings...”, p.1. 134 CDIJUM, Actas del Comité Central, 9 y 16 dic. 1975. 
Sus preocupaciones se vieron reforzadas por la sospecha de que los judíos estadounidenses no eran sensibles a las reglas tácitas con las cuales se conducía la comunidad mexicana, y temían que, aun con las mejores intenciones, los estadounidenses no supieran manejar un encuentro frontal con el presidente, lo que podría traer serias consecuencias a la comunidad judía de México. Por su parte, la delegación de Estados Unidos se asombró frente a esta respuesta, lo que indica lo poco que conocía la situación y la mentalidad de sus correligionarios mexicanos. Trataron de tranquilizarlos y les aseguraron que en todo momento serían respetuosos y corteses, "aun si la reunión no era satisfactoria". ${ }^{135}$

A pesar del compromiso, y para disminuir los riesgos, los judíos mexicanos decidieron no asistir a la reunión. Se ha señalado la paradoja de que al asumir su identidad como mexicanos, con el fin de evitar cualquier tipo de confrontación con el gobierno, los mexicanos judíos al mismo tiempo cancelaron, como mexicanos y como judíos, el derecho a expresar su opinión frente a las decisiones gubernamentales, internalizando así una cultura política nacional no participativa. ${ }^{136}$

Mientras la comitiva estadounidense se reunía con los judíos de México, recibieron una llamada de Miguel Alemán, que invitó a tres o cuatro miembros de la delegación a su casa. Llegó por ellos la limusina de Alemán y cuando uno del grupo se sentó adelante, se tropezó con una ametralladora que lo sobresaltó. En su casa, Alemán les habló acerca de Echeverría, de su pasado, de sus deseos de suceder

135 AJC, Foreign Affairs Department, c. \# 4, carp. Zionism Resolution, Reaction-Boycott, Richard Maass, "Observations on Meetings...”, p. 1.

136 Bokser Liwerant, "Fuentes de legitimación de la presencia judía en México", p. 334. 
a Waldheim y de sus intentos por ser un puente entre Occidente y el Tercer Mundo. Les dijo que el presidente era un hombre emocional, que respondía más al contacto personal que a cartas, por lo que una reunión con él podría ser más productiva. Les advirtió acerca del "estilo” que debían usar al dirigirse al presidente, con tanto énfasis como lo habían hecho ya los miembros de la comunidad judía mexicana. ${ }^{137}$

Les preguntó si había miembros de la comunidad judía mexicana a quienes quisieran invitar a la reunión. Como resultado de su junta con los líderes comunitarios, respondieron que no había ninguno. ${ }^{138}$

Antes de tomar la determinación de viajar a México, los representantes judíos habían comentado el tema con el Departamento de Estado de Estados Unidos y acordaron mantenerlo informado del desarrollo. Incluso habían pensado invitar al embajador a cenar. ${ }^{139}$ La reunión con Miguel Alemán imposibilitó los planes del encuentro informal con Jova; sin embargo, al día siguiente, a las 9:30 de la mañana, se vieron con tres miembros del personal de la embajada de Estados Unidos en México, entre ellos el encargado de asuntos políticos, Walter Estep. ${ }^{140}$

La delegación percibió que los funcionarios de Estados Unidos que los recibieron estaban complacidos de que los

137 AJC, Foreign Affairs Department, c. \# 4, carp. Zionism Resolution, Reaction-Boycott, Richard Maass, “Observations on Meetings...”, p. 1. 138 YUA-IM, c. 15, carp. 4, “Transcript Mexico Meeting...”, 12 dic. 1975, parte 1, p. 1.

139 NSA, Telegram STATE 290968, Ingersoll, to AMEmbassy Mexico. Immediate, Confidential, "Mexico and the anti-Zionism Resolution", 10 dic. 1975 , p. 2.

140 AJC, Foreign Affairs Department, c. \# 4, carp. Zionism Resolution, Reaction-Boycott Richard Maass, “Observations on Meetings...”, p. 2. 
judíos estadounidenses hubieran aceptado esa "invitación sin precedentes", y pensaban que éste era un buen presagio para las relaciones "estadounidenses-judías", así como para las relaciones "estadounidenses-mexicanas". ${ }^{141}$ Aun así, algunos temían que el propósito de Echeverría fuera reclamar a los judíos estadounidenses los rumores que afirmaban que Echeverría estaba recibiendo dinero de los árabes. ${ }^{142}$ Estep no era optimista acerca de la cita con Echeverría y dudaba que México cambiara su postura; aun así, les pidió mantenerlo al tanto. ${ }^{143}$

A las 12 del mediodía, llegaron a Los Pinos. Echeverría les dio una bienvenida muy cálida, pero entonces comenzó lo peculiar. El presidente habló sin interrupción durante una hora cuarenta y cinco minutos. Al decir de los presentes, "Los primeros setenta minutos de su discurso serían muy aceptables en El Cairo, Damasco o Ammán y los últimos treinta minutos serían igualmente aceptables en un mitin de la UJA [United Jewish Appeal]”. ${ }^{144}$ El monólogo de Echeverría fue grabado y transcrito. Es muestra de un pensamiento poco claro y desordenado, donde el leitmotiv del "malentendido" se repite infinidad de veces. ${ }^{145}$

141 HA, c. 66, carp. Mexico, Mrs. Rose Matzkin NB 12/18/75.

142 NSA, Cable MEXICO 10350, Calderhead to Secretary of State, Confidential "Proposed dialogue on Gom policy towards Zionism”, 25 nov. 1975 , p. 2.

143 AJC, Foreign Affairs Department, c. \# 4, carp. Zionism Resolution, Reaction-Boycott, Richard Maass, “Observations on Meetings...”, p. 2. 144 AJC, Foreign Affairs Department, c. \# 4, carp. Zionism Resolution, Reaction-Boycott, Richard Maass, “Observations on Meetings...”, p. 2. El United Jewish Appeal es una organización judía de beneficencia.

145 YUA-IM, c. 15, carp. 4, “Transcript Mexico Meeting...”, 12 dic. 1975, passim. 
Echeverría habló con detalle acerca de su gira por Medio Oriente y, específicamente, acerca de su visita a Israel. ${ }^{146} \mathrm{El}$ presidente se esforzó en demostrar su buena relación con los judíos mexicanos una y otra vez: "yo les digo: algunos de mis mejores amigos son judíos distinguidos en México". ${ }^{147}$

Mencionó el desayuno que había tenido con líderes comunitarios mexicanos y cómo entre los presentes tenía conocidos de cuando había sido subsecretario y secretario de Gobernación, "porque nos hemos tratado a través de los años”. Aseguró que muchas veces había ayudado a la comunidad por medio de "mi propia actividad personal para resolver los problemas, algunas veces problemas muy dolorosos, de judíos que fueron perseguidos". ${ }^{148}$

Al mismo tiempo, dio a entender que había límites en la relación y que era él quien los establecía, pues contó que los miembros de la comunidad judía habían sugerido "que arreglara yo una reunión, desayuno o comida, con dos o tres mil personas. Les dije que no se precipitaran, que no trataran de simplificar las cosas"..$^{149}$

Afirmó que su principal interés en la reunión no era económico, sino más bien una cuestión de "moralidad política". 150

146 YUA-IM, c. 15, carp. 4, “Transcript Mexico Meeting...”, 12 dic. 1975, parte 3, pp. 6 y 7. En 1975 Echeverría hizo una gira a Medio Oriente que incluyó a Israel.

147 YUA-IM, c. 15, carp. 4, “Transcript Mexico Meeting...”, 12 dic. 1975, parte 3, p. 4.

148 YUA-IM, c. 15, carp. 4, “Transcript Mexico Meeting...”, 12 dic. 1975, parte 5, p. 4.

149 YUA-IM, c. 15, carp. 4, “Transcript Mexico Meeting...”, 12 dic. 1975, parte 7, pp. 2-3.

150 YUA-IM, c. 15, carp. 4, “Transcript Mexico Meeting...”, 12 dic. 1975, parte 2, p. 1. 
Y lo repitió más tarde: "Para mí es algo - cómo puedo decirlo- profundo, de moralidad política, créanme". ${ }^{151}$

El presidente sí hizo alusión a la importancia de que México fuera de nuevo el objetivo turístico y económico de los judíos estadounidenses, e insistió en que lo contemplaran como opción para hacer negocios y para viajar. ${ }^{152}$

En aquel discurso confuso y contradictorio, predicó con una retórica que disociaba lo que decía de lo que hacía. De esta forma, al mismo tiempo que asumió la responsabilidad del voto en Naciones Unidas, Echeverría afirmó repetidas veces que tenía una opinión positiva acerca del sionismo:

Ahora bien, no somos antisionistas. Entendemos [...] Israel como el hogar tradicional e histórico de los judíos.

Pero si me preguntan: “¿Qué piensa del sionismo?” les digo que es profundamente honorable; que ha sido un pilar de salvación y un camino para la supervivencia del pueblo judío.

Ahora, yo les digo - y esto está siendo grabado y lo pueden publicar-: el sionismo es profundamente honorable. ${ }^{153}$

En cuanto al voto en la ONU, afirmó que los rumores acerca del dinero recibido eran falsos “¿Por qué lo hice? [...] no presionado, como se ha dicho, por los petrodólares de los países árabes" ${ }^{154}$ Tampoco por sus aspiraciones al cargo de

151 YUA-IM, c. 15, carp. 4, “Transcript Mexico Meeting...”, 12 dic. 1975, parte 7, p. 2.

152 YUA-IM, c. 15, carp. 4, “Transcript Mexico Meeting...”, 12 dic. 1975, parte 4, pp. 4-5.

153 YUA-IM, c. 15, carp. 4, “Transcript Mexico Meeting...”, 12 dic. 1975, parte 3, pp. 8-9, y parte 4, pp. 1-4.

${ }_{154}$ YUA-IM, c. 15, carp. 4, “Transcript Mexico Meeting...”, 12 dic. 1975, parte 2, p. 3. 
secretario general de la onu. Reconoció que le atraía el puesto, pero agregó que "ni la propuesta del Tratado ni ese voto - tan discutible y con tantos aspectos, que he explicadotienen nada que ver con este asunto". ${ }^{155}$

El presidente pareció indicar que el voto fue inspirado por un intento de suavizar la posición de Israel. ${ }^{156}$ Por eso, dijo contradictoriamente, México tenía que votar a favor de la condena al sionismo como racismo, a pesar de no ser antisionista: "No podía tomar ninguna otra posición, no somos antisionistas; somos amigos de Israel". ${ }^{157}$

Echeverría reconoció que la resolución que definía al sionismo como racismo no era ideal: "Si me dicen que el texto del voto no está exactamente en los términos que ustedes aceptarían que presionarían para influenciar hacia una política de diálogo para resolver el problema palestino, yo les digo: eso es cierto". ${ }^{158}$

A continuación sigue una de las partes más imprecisas de su exposición. Aun tratando de poner orden en el discurso del presidente, eliminando las repeticiones constantes y uniendo los párrafos diseminados en los cuales se refiere al motivo del voto mexicano, no emerge una visión clara que justifique el voto que emitió México a favor de una declaración cuyo texto el mismo Echeverría calificó como

155 YUA-IM, c. 15, carp. 4, “Transcript Mexico Meeting...”, 12 dic. 1975, parte 7, p. 1. Como se ha señalado, el viaje sí estaba relacionado.

156 YUA-IM, c. 15, carp. 4, “Transcript Mexico Meeting...”, 12 dic. 1975, parte 3, pp. 8-9.

157 YUA-IM, c. 15, carp. 4, “Transcript Mexico Meeting...”, 12 dic. 1975, parte 4, p. 1.

158 YUA-IM, c. 15, carp. 4, “Transcript Mexico Meeting...”, 12 dic. 1975, parte 6, p. 1. 
inadecuado para lograr los propósitos de diálogo. Reconoció que "todos estamos en un estado de confusión en Naciones Unidas. Por eso hacía falta una explicación del voto que yo ordené", pero explicarlo "Hubiera requerido un esfuerzo dialéctico considerable". ${ }^{159}$

En su respuesta, Seymour Graubard reconoció el gran honor que se les había hecho al invitarlos, siendo que no constituían un grupo oficial. ${ }^{160}$ Efectivamente, estaban muy conscientes de que el viaje para reunirse con Echeverría y todo lo que ahí estaba sucediendo era "único", y así lo dijeron incluso en sus reportes internos. Les pareció sorprendente que "Un grupo de ciudadanos estadounidenses de fe judía, es invitado a reunirse con el Presidente de una república soberana para discutir un asunto de política exterior y para obtener un cambio en la posición declarada públicamente por esa república". ${ }^{161}$

Reconocieron también la amistad que el presidente había expresado hacia los judíos mexicanos: "Sus muchos amigos dentro de la comunidad judía de México nos han asegurado lo siguiente: que lo consideran su amigo y saben que siempre lo considerarán su amigo". ${ }^{162}$

Le expresaron que como turistas habían sido felices en México y sabían de primera mano que era cierto lo que el

159 YUA-IM, c. 15, carp. 4, “Transcript Mexico Meeting...”, 12 dic. 1975, parte 4, pp. 3-4.

160 YUA-IM, c. 15, carp. 4, “Transcript Mexico Meeting...”, 12 dic. 1975, parte 8, p. 1.

161 AJC, Foreign Affairs Department, c. \# 4, carp. Zionism Resolution, Reaction-Boycott, Richard Maass, "Observations on Meetings...”, p. 1. 162 YUA-IM, c. 15, carp. 4, “Transcript Mexico Meeting...”, 12 dic. 1975, parte 8, p. 2. 
presidente afirmaba acerca de la ausencia de antisemitismo en el país. ${ }^{163}$ Y le pidieron: "Sr. presidente, todos los miembros de esta delegación amamos a México; queremos regresar a México, queremos que nuestros amigos estén contentos de venir a México". ${ }^{164}$

El argumento principal de la delegación fue el siguiente: profesaban un gran amor por México y por su gente, y dijeron en los términos más claros que ansiaban regresar a México como turistas. Pero eso no estaba en sus manos, pues la posición actual de México en la ONU respecto a Israel les hacía imposible volver; a los judíos y a todos los estadounidenses no judíos que compartían sus sentimientos, pues ninguno de ellos entendía el voto mexicano. Y aprovecharon entonces para subrayar que aunque eran organizaciones judías, sus contactos incluían a estadounidenses judíos y no judíos. ${ }^{165}$

Al final de la reunión, y con el fin de lograr una declaración clara y sin ambigüedades por parte de Echeverría en sus observaciones finales, Graubard le preguntó: "Señor presidente, ¿podemos asumir por sus comentarios que México, bajo su dirección, no volverá a votar en Naciones Unidas de una manera que podría ser malentendida como antisionista?”. Antes de que pudiera recibir la traducción al inglés, el presidente asintió con la cabeza y dijo: "sí, sí". ${ }^{166}$ Y afirmó

163 YUA-IM, c. 15, carp. 4, “Transcript Mexico Meeting...”, 12 dic. 1975, parte 8, p. 2.

164 YUA-IM, c. 15, carp. 4, “Transcript Mexico Meeting...”, 12 dic. 1975, parte 9, p. 1.

165 YUA-IM, c. 15, carp. 4, “Transcript Mexico Meeting...”, 12 dic. 1975, parte 9, pp. 1-2.

166 AJC, Foreign Affairs Department, c. \# 4, carp. Zionism Resolution, Reaction-Boycott, Richard Maass, “Observations on Meetings...”, p. 3. 
que había dado instrucciones precisas a Rabasa y González Robles, jefe de la Delegación Mexicana en la onu, para que fueran "especialmente cautelosos" y para que distinguieran "a nuestra política tercermundista de todo lo que pudiera siquiera aparentar ser antisionismo". ${ }^{167}$

La representación estaba extasiada, sentían que habían logrado todos sus propósitos, y así lo dijeron: "Regresamos a Estados Unidos con un sentimiento de verdadero acuerdo y de logro. Haremos todos los esfuerzos posibles para restaurar el entendimiento que fue empañado por la ausencia de aclaraciones en las últimas semanas". La reunión terminó con un brindis en honor de Echeverría y otro en honor de Israel. ${ }^{168}$

Siguió una comida kosher, acompañada con vino israelí, ${ }^{169}$ a la que sí acudieron algunos judíos mexicanos invitados por Echeverría. ${ }^{170}$ Éstos no quisieron participar en la reunión de trabajo por temor a que su presencia fuera "malinterpretada", pero, una vez transcurrida la junta, y más aún al constatar los excelentes resultados de ella, participaron en la comida. ${ }^{171}$

167 YUA-IM, c. 15, carp. 4, “Transcript Mexico Meeting...”, 12 dic. 1975, parte 8, p. 9.

168 YUA-IM, c. 15, carp. 4, “Transcript Mexico Meeting...”, 12 dic. 1975, parte 9, p. 3 y parte 10, p. 2

169 YUA-IM, c. 15, carp. 7,"Report for the Year Ending March 31, 1976" "V. The trouble with Mexico", p. 34.

170 AJC, Foreign Affairs Department, c. \# 4, carp. Zionism Resolution, Reaction-Boycott, Richard Maass, “Observations on Meetings...”, p. 4. 171 Oliverio Duque Juárez, “Todos Satisfechos. Se Reunió LE con Dirigentes Judíos”, El Sol de México (13 nov. 1975), p. 12. Éstos fueron Sergio Nudelstejer, Simón Feldman, Enrique Elías, Gregorio Wallerstein, Jacobo Zabludovsky y León Davidoff. 
Después de la comida, comenzó una conferencia de prensa oficial dirigida por el licenciado Mauro Jiménez Lazcano, director general de Información de la Presidencia, frente a periodistas de México y corresponsales extranjeros, radio y televisión, que resumió lo acordado en la junta, en palabras de la Presidencia y del jefe de la delegación de judíos estadounidenses. ${ }^{172}$ Cabe resaltar que los judíos mexicanos no participaron en la conferencia de prensa.

En dicha conferencia se presentó "un número inusitado de corresponsales extranjeros", ${ }^{173}$ porque había conciencia de lo especial o inusual que estaba siendo todo el proceso, así como de la importancia de lo que de éste resultara. Al final se abrió una sesión de preguntas y respuestas. CBS News, reflejando lo extraño de la situación, preguntó cómo había llegado la delegación a México, ¿acaso ellos pidieron la entrevista? Graubard respondió que ellos no la solicitaron, sino que el presidente los había invitado por medio de Miguel Alemán. ${ }^{174}$

Jorge Avilés, de El Universal, hizo una pregunta que estaba en la mente de muchos mexicanos: si habían sido 72 los países que votaron a favor de la resolución, ¿ por qué la reacción de la comunidad judía de Estados Unidos y Canadá había sido solo contra México? Graubard respondió que la gente no boicoteó solo a México. Que sus organizaciones

172 AJC, Bertram Gold Executive Papers, carp. United Nations 1975, Zionism, Mexico, "Los Pinos, diciembre 12 de 1975. Conferencia de Prensa ...”, p. 1.

173 Oliverio Duque Juárez, “Todos Satisfechos. Se Reunió LE con Dirigentes Judíos”, El Sol de México (13 nov. 1975), p. 12.

174 AJC, Bertram Gold Executive Papers, carp. United Nations 1975, Zionism, "Los Pinos, diciembre 12 de 1975. Conferencia de Prensa...”. 
habían recibido millares de solicitudes de personas que querían tener las tarjetas de bolsillo que contenía la lista de los países y cómo había votado cada uno, para tomarlo en cuenta en futuros viajes. Aseguró que el turismo había disminuido también en otros sitios, y el hecho de que a México fuera hacia donde más había bajado era un tributo a México, pues indicaba que era el país que los estadounidenses más visitaban, gracias a su clima agradable y su "cálida bienvenida”. Más estadounidenses viajaban a México que a todos los demás países juntos, por ello era natural que el turismo hubiese decrecido más en México que en otros lados. ${ }^{175}$

Graubard aclaró que no sólo eran judíos los que dejaron de viajar a México como consecuencia del voto mexicano a la Resolución 3379. También la población no judía se rehusaba a viajar a México. Pero agregó: "Estamos seguros de que ahora todo se aclarará". Frente a la pregunta de cuándo terminaría el boicot, insistió en que el problema estaba mal definido. Señaló que "no ha habido ningún boicot organizado por parte de ninguna de las organizaciones judías, ni en Estados Unidos ni en Canadá”. ${ }^{176}$

Graubard afirmó varias veces que, como resultado de la plática que habían sostenido con Echeverría, regresarían a Estados Unidos y Canadá y explicarían que nunca se tuvo la intención de equiparar al sionismo con el racismo: "Y estamos seguros de que las buenas relaciones que siempre han

175 AJC, Bertram Gold Executive Papers, carp. United Nations 1975, Zionism,"Los Pinos, diciembre 12 de 1975. Conferencia de Prensa...".

176 AJC, Bertram Gold Executive Papers, carp. United Nations 1975, Zionism,"Los Pinos, diciembre 12 de 1975. Conferencia de Prensa...". La pregunta fue de Graciela Leal, del noticiero 24 Horas. 
prevalecido entre México y la población judía de Estados Unidos y Canadá continuarán”. ${ }^{177}$

Terminada la conferencia de prensa, llamaron a la embajada de Estados Unidos para informar sobre el resultado. Al respecto, el embajador Jova habría de escribir al Departamento de Estado unos días después:

Una semana extraordinaria. El gobierno hizo todo lo posible, hasta casi humillarse, para transmitir su mensaje. Los líderes judíos informaron que habían rechazado dos invitaciones previas para visitar México y reunirse con Echeverría y sólo aceptaron la tercera invitación a causa de la insistencia con la que se hizo. ${ }^{178}$

Posteriormente los miembros de la delegación regresaron al hotel y tuvieron una junta con cuatro miembros de la comunidad judía mexicana para lo que llamaron el post mortem de lo sucedido durante el día. Ahí, Mort Rosenthal, director de Latin American Affaires del Anti Difamation League del B'nai B'rith, los “criticó severamente [...] por haber dejado que la situación [del voto mexicano] se desarrollara hasta una etapa de crisis antes de llamar para pedir ayuda". Rosenthal les reclamó que habían tratado de mantener el tema en silencio y esto había sido un error. Les dijo que "en el futuro debería darse una mejor comunicación y un intercambio" y enfatizó que "en este caso no había existido". ${ }^{179}$

177 AJC, Bertram Gold Executive Papers, carp.: United Nations 1975, Zionism, "Los Pinos, diciembre 12 de 1975. Conferencia de Prensa...". 178 NSA, Cable 1975MEXICO11095, Jova to Secretary of State, "President Echeverría meets with North American Jewish Leaders", Confidential, Mexico, 16 dic. 1975, p. 2.

179 AJC, Foreign Affairs Department, c. \# 4, carp. Zionism Resolution, Reaction-Boycott, Richard Maass, “Observations on Meetings...”, p. 4. 
Por su parte, los judíos mexicanos quedaron satisfechos con el resultado de la reunión, pues ésta se había realizado en términos muy amistosos. ${ }^{180}$

Finalmente, la delegación regresó a Estados Unidos.

Parecía ser que los malentendidos se habían aclarado, la confrontación había cesado, el conflicto estaba resuelto y se evitaría parte del costo económico, pues aún podría recuperarse una parte significativa de las vacaciones de invierno.

EL VOTO MEXICANO DEL 15 DE DICIEMBRE DE 1975

A pesar de que Echeverría se comprometió a que no habría ningún "malentendido" futuro respecto al voto de México, la comitiva que viajó a México decidió que el reporte a sus respectivas organizaciones se haría después del voto en la ONU del 15 de diciembre, para observar el comportamiento de México, y "si México hacía las declaraciones apropiadas al momento del voto, quedó claro que ya no exhortaríamos a los turistas estadounidenses a evitar México". ${ }^{181}$

Llegó el 15 de diciembre. Ese día se votarían en la ONU las resoluciones relativas a la Conferencia del Año de la Mujer, que tuvo lugar en México. Ésta había dado origen a varias resoluciones, a un Programa de Acción y a la Declaración México. El Programa de Acción no tenía referencias al sionismo, pero la Declaración México contenía en su seno

180 AJC, Foreign Affairs Department, c. \# 33, carp. Mexico 1975-1976, Zionism Resolution, Reaction-Boycott, Sergio Nudelstejer a Morris Fine, "Mexico's vote against Zionism", 16 dic. 1975, p. 2.

181 AJC, Foreign Affairs Department, c. \# 4, carp. Zionism Resolution, Reaction-Boycott, Richard Maass, "Observations on Meetings...”, p. 4. 
cláusulas antisionistas. ${ }^{182}$ México no sólo era patrocinador de la Declaración México, sino que además le era importante que fuese adoptada, pues llevaba su nombre.

Varios países miembros de la ONU, entre ellos Australia, Austria y Finlandia, declararon antes de la votación en la Tercera Comisión que, mientras que sí apoyarían la resolución en su conjunto, ya que constituía una base sólida para el Decenio de la Mujer, tenían la intención de abstenerse o de votar en contra de los párrafos operativos que se votarían por separado. Explicaron que esto se debía a las reservas que albergaban respecto a la Declaración México, pues el texto equiparaba el sionismo con la discriminación racial.

Italia declaró que los nueve estados miembros de la Comunidad Económica Europea se abstendrían en la votación debido a la mención del sionismo entre las fuerzas que se oponían a la emancipación de la mujer. Canadá, Costa Rica, Estados Unidos y otros, expresaron puntos de vista similares.

El representante de Israel dijo que aunque apoyaba plenamente el esfuerzo para mejorar la condición y el papel de las mujeres, consideraba que la Conferencia del Año de la Mujer había sido explotada para tener efectos antisemitas. Por ello, avisó que votaría en contra de las resoluciones que implicaran la aprobación completa de las medidas adoptadas en la Conferencia. ${ }^{183}$

De manera que hubo cinco tipos de reacciones posibles frente al contenido antisionista de la Declaración México cuando se presentó a votación en la ONU:

182 Véase Compilación, pp. 12 y 17.

183 UN Year Book, 1975, p. 659. http://unyearbook.un.org/unyearbook. html?name=1975index.html acceso 27 de noviembre de 1975 . 
- Votar contra la Declaración en su forma total, como lo hizo Israel.

- Abstenerse en la votación de la Declaración en su forma completa, como lo hicieron 25 países (entre ellos los miembros de la Comunidad Económica Europea).

- Votar a favor de la Declaración en su forma completa, pero votar en contra de las cláusulas antisionistas, como lo hicieron 23 países.

- Votar a favor de la Declaración en su forma completa, pero abstenerse de votar en las cláusulas antisionistas, como lo hicieron 26 países.

- Votar a favor de la Declaración en su forma completa, y votar a favor también de las cláusulas antisionistas, como lo hicieron 83 países (en su mayoría, el bloque árabesoviético).

México formó parte de los 83 países que votaron a favor tanto de la Declaración México como de todas sus cláusulas antisionistas. $^{184}$

Ya desde el 6 de diciembre, Salvador Gallástegui, subsecretario de Relaciones Exteriores, le dijo al embajador estadounidense Jova que México votaría a favor de la Declaración México, pero con una explicación del voto. ${ }^{185}$

Como he mencionado, para México era muy importante que la declaración que llevaba su nombre fuera adoptada. De hecho, en el seno de Naciones Unidas, en las discusiones

\footnotetext{
${ }^{184}$ Yitzhak Rabi, "Mexico votes for General Assembly Resolution Condemning Zionism”, JTA, Daily Nerws Bulletin, vol. XLII, núm. 238, $58^{\text {th }}$ Year, 17 dic. 1975.

185 NSA, Telegram MEXICO 10762, Jova to Secretary of State, Confidential, "Mexico and the anti-Zionism Resolution", 6 dic. 1975, pp. 1-2.
} 
previas al voto en el Tercer Comité, Aída González Martínez, de la delegación de México, trató de convencer a los delegados de otros países para que votaran a favor. Pues aun si "tenían reservas acerca de algunas de las provisiones y las decisiones adoptadas en el año internacional de la mujer, no debían considerar sus reservas un obstáculo para votar a favor $[. .$.$] en todo caso podrían explicar sus votos". { }^{186}$ Es obvio cuáles eran tales "reservas": la definición de sionismo como una forma de racismo.

Incluso Rabasa en sus memorias, a pesar de reconocer el error respecto al voto de sionismo=racismo, escribió que el voto del 15 de diciembre tenía necesariamente que haber sido a favor, para que México fuera congruente con la manera en que había votado por la Declaración México y por la Resolución 3379 en la ONU. ${ }^{187}$ Sin embargo, Rabasa también reconoció la necesidad de una explicación, para manifestar "nuestra preocupación en referencia con los mencionados párrafos 24 y 26 de la Declaración México". ${ }^{188}$

Efectivamente, a instancias de Rabasa, ${ }^{189}$ la delegada mexicana, Aída González, el 15 de diciembre leyó una aclaración previa al voto mexicano. La parte crucial de la aclaración decía lo siguiente:

186 AJC, Foreign Affairs Department, c. \# 4, carp. Zionism Resolution, Reaction-Boycott, "From Summary Record, Third Committee, Wednesday, December 3, AM".

187 Rabasa, Canciller de México, pp. 149 y 153.

188 Rabasa, Canciller de México, p. 151. Estos párrafos definían al sionismo como racismo.

189 Rabasa, Canciller de México, p. 153. 
[...] si entendemos por sionismo la realización de las aspiraciones nacionales legítimas del pueblo judío dentro del marco de la Carta de Naciones Unidas, nuestro voto no debe interpretarse en forma alguna como una aceptación de la equiparación que pretende hacerse en los párrafos 24 y 26 ante el sionismo y otras políticas que, como el colonialismo o el apartheid, México ha condenado siempre. ${ }^{190}$

Tanto a los observadores de las organizaciones judías como a la prensa, les pareció que la "aclaración” leída por Aída González no había explicado a ciencia cierta por qué México votaba a favor de los dos párrafos antisionistas siendo que había otras opciones de voto, como se ha explicado, y que muchos países de Latinoamérica se abstuvieron. ${ }^{191}$

Además, llamó la atención de muchos que la delegada mexicana sólo hubiera hablado en contra de la ecuación sionismo-racismo de manera condicional: "si entendemos $[\ldots]$ ".. ${ }^{192}$

Los judíos estadounidenses que habían asistido al debate en la ONU como observadores acusaron a México de haberlos engañado. Al oír el voto de México, hubo una "consternación generalizada” ${ }^{193}$ y abandonaron la sala, "aturdidos y

190 Rabasa, Canciller de México, p. 151.

191 AJC, United Nations-Anti-Zionism, "Memorandum of Morris Fine to Area Directors- Mexico's vote at the UN-December 15”, 16 dic. 1975, p. 1. Y Yitzhak Rabi, "Mexico votes for General Assembly Resolution Condemning Zionism”, JTA Daily News Bulletin, vol. XLII, núm. 238, $58^{\text {th }}$ Year, 17 dic. 1975.

192 Michael J. Berlin, “Mexican 'Double Cross' Seen in UN Zionism Vote”, New York Post (16 dic. 1975), p. 5.

193 YUA-IM, c. 15, carp. 7, "Report for the Year Ending March 31, 1976" "V. The trouble with Mexico", p. 34. 
furiosos" ${ }^{194}$ Públicamente, los líderes judíos calificaron el voto de México como "muy lamentable"; en privado, lo llamaron "una traición". ${ }^{195}$

También el público quedó atónito. Esta carta de un ciudadano de Estados Unidos escrita unos días después de la votación es representativa de muchas:

Su delegado en la onu votó Sí [...] y sin embargo usted dice que al votar Sí quería decir No. Eso es realmente difícil de entender.

Su Ministro de Relaciones Exteriores Sr. Rabasa trató de explicar a los israelíes que su Sí realmente era No [...]

...

Muchos de los profesores de mi escuela hemos debatido esta cuestión a profundidad. El consenso es que votar Sí significa Sí y No significa No. ${ }^{196}$

Las reacciones fueron inmediatas. El Presidents' Conference expresó en una reunión íntima una "gran decepción [...] tanto con el voto de la noche pasada como con la reserva expresada”, y públicamente anunció:

Estamos profundamente preocupados por el fracaso de la representante de México en su intento de dejar en claro en su voto y en su declaración de anoche en la ONU, la posición que

${ }^{194}$ UN, “Jews Hit Mexico’s New Vote”, The Washington Post (17 dic. 1975), sec. A, p. 13.

195 Michael J. Berlin, “Mexican 'Double Cross' Seen in UN Zionism Vote”, New York Post (16 dic. 1975), p. 5.

196 AHSRE, L-2265 NC Sardinero, VIII/411.11 (XXX) (06)/68 Primera Parte, Jacob Isseroff al presidente Echeverría, 18 dic. 1975. 
nos transmitió el presidente de México a los líderes judíos la semana pasada [...]. ${ }^{197}$

Agregó que cada organización deliberaría si habría un cambio en las políticas respecto a sus viajes a México o no. Y comentó que, por el momento, ése no parecía ser el caso. ${ }^{198}$

Para comprender la reacción de las organizaciones judías estadounidenses, es necesario remontarnos al viaje que sus representantes realizaron a México el 12 de diciembre. Éste fue precedido y seguido por una serie de profundos análisis acerca de las expectativas que tenía la delegación, del significado de la reunión con Echeverría y de sus implicaciones para el voto mexicano.

Sabiendo que se aproximaba el voto respecto a la Conferencia del Año Internacional de la Mujer, durante la reunión Graubard había preguntado al presidente explícitamente al respecto. Echeverría contestó enfáticamente que Rabasa había viajado a Nueva York para cerciorarse de que se hiciera "una excepción en el punto sobre el sionismo [...] con el fin de asegurarse de que no hay duda de que el voto de México no es contra el sionismo". ${ }^{199}$

Los judíos estadounidenses estaban conscientes de que México no estaría dispuesto a votar en contra de la Declaración México, y por ello sus aspiraciones eran mesuradas:

197 AJC, United Nations-Anti-Zionism, "Memorandum of Morris Fine to Area Directors-Mexico’s vote at the UN-December 15”, 16 dic. 1975, p. 2.

198 AJC, United Nations-Anti-Zionism, "Memorandum of Morris Fine to Area Directors-Mexico's vote at the UN-December 15”, 16 dic. 1975, p. 2.

199 YUA-IM, c. 15, carp. 4, “Transcript Mexico Meeting...”, 12 dic. 1975, parte 5, p. 2. 
Con el fin de que la intención del voto de México sea entendido claramente, es esencial que el delegado mexicano declare explícitamente que México se opone a la equiparación del sionismo con el racismo o con cualquier otra forma de discriminación. Esta explicación del voto por el delegado de México ante la Asamblea General de Naciones Unidas debe hacerse en el momento preciso en que el voto de México se haga. ${ }^{200}$

El 16 de diciembre, al día siguiente de la votación en la Asamblea General, el Presidents' Conference llevó a cabo una junta. Aunque había desacuerdo entre los presentes acerca de si Echeverría se había comprometido o no a que cambiaría el voto de México, de lo que todos estaban seguros era de que les había garantizado que la delegación de México en la ONU disociaría claramente a su gobierno de la ecuación sionismo-racismo. Sin embargo, la explicación les pareció a todos insuficiente y "por lo menos equívoca”. ${ }^{201}$

Por ello, tras la votación del 15 de diciembre, la presidenta de Hadassah le envió un telegrama personal a Echeverría, diciéndose "profundamente afligida” y expresando la decepción que sintieron los miembros de la delegación. ${ }^{202}$

El voto de México a favor de las cláusulas antisionistas, combinado con la "aclaración” confusa y poco enérgica de

${ }^{200}$ AJC, United Nations-Anti-Zionism, "Memorandum of Morris Fine to Area Directors-Mexico's vote at the UN-December 15", 16 dic. 1975, p. 2.

201 AJC, United Nations-Anti-Zionism, "Memorandum of Morris Fine to Area Directors-Mexico's vote at the UN-December 15", 16 dic. 1975, p. 1.

${ }^{202}$ HA, c. 66, carp. Mexico, Telegrama de Rose Matzkin a Luis Echeverría. También en AHSRE, VIII/411.11(XXX)(08)/68 Primera Parte, L-2262 Sardinero, Dirección General de Organismos Internacionales. 
la delegada mexicana, tuvo un efecto explosivo y contraproducente para que se levantara el boicot. Los periódicos, tanto de Nueva York como de Washington, publicaron anuncios de "personalidades judías prominentes en los negocios, las profesiones y el mundo del entretenimiento" protestando por los votos de México y apoyando al boicot. ${ }^{203}$

Aída González cuenta que, tras el voto, el expresidente Miguel Alemán la llamó directamente, lo que la sorprendió sobremanera pues ella había sido tan sólo el vocero, y le reclamó a gritos el voto, diciéndole que tenían que cambiar de actitud o habría graves consecuencias para México. ${ }^{204}$

La comunidad judía mexicana estaba muy inquieta por cómo se estaba desarrollando el asunto. Sergio Nudelstejer, en un esfuerzo por calmar los ánimos, le escribió al AJC al día siguiente de la votación en la ONU, enumerando aquellos puntos que le parecían señalar un "cambio notable por parte del gobierno" en cuanto a la posición de México frente al sionismo, y que no debían ser olvidados en la toma de decisiones. Los podemos resumir así: Echeverría "finalmente" había aceptado una entrevista con representantes de la comunidad judía mexicana; había enviado a Rabasa a Israel, y había invitado a México a una delegación de judíos de Estados Unidos y Canadá.

Nudelstejer reconoció que aún no se habían dado cambios en el voto mexicano en la onU, pero agregó que "estos

${ }^{203}$ James Nelson Goodsell, "Anti-Zionist vote in UN draws reprisals by private US groups. Jewish boycott cuts deeply into Mexican tourism”, Latin America correspondent of The Christian Science Monitor (30 dic. 1975), p. 5.

204 Ariela Katz Gugenheim. Entrevista con Walter Astié-Burgos, 28 nov. 2011. 
cambios vendrán por delante", como lo habían anunciado tanto Echeverría como Rabasa. Reconoció que "las presiones de Estados Unidos a México fueron positivas”, pero apuntó que

[...] hay un límite para ellos, y consideramos que [el boicot] debe ser detenido a causa de las manifestaciones de buena voluntad del gobierno mexicano [...] El hecho de no detener el boicot estadounidense contra México, sin duda molesta al gobierno de este país, e influirá de una manera muy negativa a la prensa, la televisión y la opinión pública de México y, lamentablemente, estamos seguros de que el pueblo mexicano tendrá un fuerte sentimiento antijudío y antinorteamericano. Sentimientos que será muy difícil olvidar en el futuro. Es por ello que consideramos de la mayor importancia hacer un esfuerzo para detener el boicot en contra de México, así como las declaraciones negativas que están realizando instituciones judías en Estados Unidos en contra de este país. ${ }^{205}$

Los líderes judíos estadounidenses escucharon las inquietudes de la comunidad judía de México y procedieron a analizarlas. Morris Fine, director de Relaciones Exteriores del AJC, habló con Nudelstejer y "discutió con él las consecuencias de todo esto en la comunidad judía de México". ${ }^{206}$ Aun así, parece ser que los argumentos esgrimidos por los judíos mexicanos no los convencieron, pues decidieron seguir

205 AJC, Foreign Affairs Department, c. \# 33, carp. Mexico 1975-1976, Zionism Resolution, Reaction-Boycott, Sergio Nudelstejer a Morris Fine, "Mexico's vote against Zionism”, 16 dic. 1975, pp. 1-3.

206 AJC, United Nations-Anti-Zionism, "Memorandum of Morris Fine to Area Directors-Mexico's vote at the UN-December 15”, 16 dic. 1975, p. 3 . 
adelante, "y los judíos estadounidenses, en forma masiva, siguieron sin viajar a México". ${ }^{207}$

De manera que la reunión convocada el 16 de diciembre por el Presidents' Conference para suspender el boicot, en lugar de terminar con él, lo ratificó.

La prensa aprovechó la noticia para hacer sonados titulares. The New York Times anunció al día siguiente de la junta del Presidents' Conference que el American Jewish Congress mantendría el boicot y que suspendería los 22 tours que tenía programados a México, para más de mil de sus miembros. ${ }^{208}$ The Washington Post reportó que muchas organizaciones e individuos estadounidenses, judíos y no judíos, seguirían cancelando sus viajes a México. ${ }^{209}$ The Miami Nerws, el periódico vespertino más leído de Miami, anunció "MEXICAN BOYCOTT BACK ON" con grandes letras en la primera plana. ${ }^{210}$

Para tranquilizar sus conciencias, o quizá porque se quedaron con la preocupación de estar causando daño a la comunidad local, las organizaciones judías de Estados Unidos se comunicaron con el Departamento de Estado de Estados Unidos para pedir su opinión. Cabe destacar que esta conversación tuvo lugar después de que la decisión de continuar con el boicot ya había sido tomada y publicitada. ${ }^{211}$

207 YUA-IM, c. 15, carp. 7, "Report for the Year Ending March 31, 1976", "V. The trouble with Mexico", p. 34.

${ }^{208}$ Eleanor Blau, "Mexico U.N. Vote Draws Protests. U.S. Jewish Leaders React to Monday Ballot That Involved Zionism", The New York Times (17 dic. 1975).

209 “Jews Hit Mexico's New Vote", The Washington Post (16 dic. 1975).

210 "Mexican boycott back on", The Miami Nerws (16 dic. 1975), primera plana.

211 En el documento del NSA no aparece la fecha de la llamada, pero 
En efecto, el embajador de Estados Unidos en México fue notificado de que Herman Edelsberg, del B'nai B'rith, había llamado al Departamento de Estado para informar acerca de la reacción del Presidents' Conference al voto del 15 de diciembre. Confirmó que el liderazgo judío estaba decepcionado, de hecho "furioso", y avisó que las organizaciones judías seguirían desalentando los viajes del turismo judío y de sus simpatizantes a México y a los demás países que habían votado así. Edelsberg afirmó que habían recibido llamadas y cartas que indicaban que esta posición contaba con un gran apoyo aun fuera de la comunidad judía. ${ }^{212}$

A raíz de esta entrevista, Kissinger le escribió al embajador estadounidense en México: "Hay preocupación entre algunos líderes judíos [de Estados Unidos] que continuar con el boicot es potencialmente perjudicial a la comunidad judía mexicana". 213

De hecho, no solo la comunidad judía mexicana estaba preocupada por el recrudecimiento del boicot. También el gobierno de Israel se inquietó. The Washington Post reportó que los diplomáticos israelíes habían recibido instrucciones de su gobierno de hablar con los líderes judíos estadounidenses con la esperanza de que terminara el boicot turístico a México. Un diplomático israelí comentó: "Honestamente

confirma las noticias aparecidas en los periódicos del 17 de diciembre, lo que permite suponer que tuvo lugar necesariamente después del 16, fecha en que se ratificó el boicot.

212 NSA, Cable, STATE 298870, Kissinger, to AMEmbassy Mexico,"Jewish reaction to UNGA vote on WICWY resolutions", 19 dic. 1975, pp. 1-2.

213 NSA, Cable, STATE 298870, Kissinger, to AMEmbassy Mexico, "Jewish reaction to UNGA vote on WICWY resolutions", 19 dic. 1975 , p. 2. 
ya queremos que se termine este asunto. No es nada bueno para nuestras relaciones con México”. ${ }^{214}$

Sin embargo, su consulta con el Departamento de Estado tranquilizó a los líderes judíos estadounidenses respecto al riesgo de causar algún daño a los judíos de México o a Israel con el boicot. En efecto, Kissinger informó a Jova que se le había explicado al representante del B’nai B’rith que México no tenía historia de antisemitismo y que además - muy a tono con la visión política global de la Realpolitik de Kissinger-: "lo más probable es que todo acuerdo entre dos naciones está basado en la percepción de beneficios mutuos, y por lo tanto no convierte a una nación en rehén de la otra [...]. Más aún, sería improbable que México culpara a Israel por acciones tomadas por la comunidad judía estadounidense”. ${ }^{215}$

Además, en sus comunicados internos, los líderes judíos estadounidenses estaban conscientes de que la decisión de seguir o no con el boicot no estaba en sus manos. Escribieron que después del voto mexicano del 15 de diciembre, se había vuelto aún más difícil detener el boicot, pues la comunidad judía de Estados Unidos se había convencido de que las simpatías de México estaban con los enemigos de Israel. Por ello, aun si el American Jewish Congress o los Jewish War Veterans hubieran restituido sus viajes a México, probablemente hubieran tenido muy pocos interesados. ${ }^{216}$

214 “Israel Seeking to End Dispute With Mexico", The Washington Post (19 dic. 1975), p. A16.

215 NSA, Cable, STATE 298870, Kissinger to AMEmbassy Mexico, "Jewish reaction to UNGA vote on WICWY resolutions", 19 dic. 1975, p. 2.

216 AJC, Bertram Gold Executive Papers, carp. United Nations 1975, Zionism, Mexico, Richard Maas to Seymour Graubard, 24 dic. 1975. 
La situación era alarmante, de manera que el 18 de diciembre de 1975, Miguel Alemán llegó a Nueva York acompañado de Miguel Guajardo, coordinador general del Consejo Nacional de Turismo, y se comunicó con Mort Rosenthal, director del Departamento de Asuntos Latinoamericanos de la Anti-Difamation League del B'nai B'rith, para pedirle una cita esa misma noche. A las 8:30 pm, se reunieron con Rosenthal, Rabbi Miller y Richard Maass en la suite de Alemán en el Hotel Pierre.

Alemán les explicó que México nunca consideró votar en contra de la Declaración de la Mujer. Los judíos estadounidenses respondieron que así lo habían entendido. En un principio esto alivió mucho a los mexicanos, pero entonces los líderes judíos le mostraron una transcripción de las declaraciones de la representante mexicana en la ONU, al momento de la votación. Además, señalaron que México pudo haber seguido el ejemplo de las democracias occidentales, es decir, podía haber votado en contra de la cláusula operativa, a pesar de que luego hubiera votado a favor de la resolución en su conjunto.

Alemán y Guajardo parecieron estar muy sorprendidos con las declaraciones de Aída González, incluso dijeron que "todo este nuevo alboroto" se podía haber evitado. No podían creer que "ella había formulado en subjuntivo la cláusula que decía que el sionismo no era racismo". ${ }^{217}$

Los estadounidenses sugirieron dos señales para sentirse más tranquilos respecto a la postura de México:

217 AJC, Bertram Gold Executive Papers, carp. United Nations 1975, Zionism, Mexico, Richard Maas to Seymour Graubard. 22 dic. 1975. Supongo que fue a raíz de esta conversación que Miguel Alemán llamó por teléfono a Aída González. 
1. Que el presidente les mandara una carta afirmando que lo que les había dicho en México seguía siendo su punto de vista.

2. Que Aída dejara su puesto, como una señal de que el presidente desautorizaba sus comentarios. ${ }^{218}$

Y así se hizo.

El 24 de diciembre, en plena Nochebuena, Miguel Guajardo viajó a Nueva York para entregar personalmente una transcripción de los discursos pronunciados durante la comida del 12 de diciembre en Los Pinos, con una carta anexa en la que especificaba que así lo hacía por órdenes del señor presidente. $^{219}$

Aída González no fue despedida, pero el titular de la Secretaría de Relaciones Exteriores de México, el canciller Emilio Rabasa, dejaría su cargo menos de una semana después.

\section{LA “RENUNCIA” DEL CANCILLER EMILIO O. RABASA}

Es bien conocido que el canciller Emilio Rabasa vivió una etapa muy difícil en las relaciones internacionales de México, "caracterizada por la incertidumbre en las decisiones de gobierno sobre temas fundamentales y por el muy especial estilo de gobernar del mandatario en turno". ${ }^{220}$ Es cierto que el mismo Rabasa la vio como una etapa espinosa, pues en sus

${ }_{218}$ AJC, Bertram Gold Executive Papers, carp. United Nations 1975, Zionism, Mexico, Carta de Seymour Graubard a Richard Maass, 22 dic. 1975, pp. 1-2.

219 YUA-IM, c. 15, carp. 4, “Transcript Mexico Meeting...”, 12 dic. 1975.

220 Sergio González Gálvez, en el prólogo a Rabasa, Canciller de México, p. 11. 
memorias la define como "el capítulo más importante y turbulento de mi vida". 221

Lo escrito por el autor Alan Riding es ejemplo de la opinión popular acerca de su fin político: "Cuando Emilio O. Rabasa, secretario de Relaciones Exteriores, pidió disculpas a Israel en un discurso improvisado en Tel Aviv, llegó demasiado lejos y fue despedido". ${ }^{222}$ Sin embargo, sostengo que lo sucedido fue más complejo y que además revela aspectos importantes del régimen de Echeverría.

Cuando Echeverría se reunió con la delegación de judíos estadounidenses, Rabasa había terminado su gira por Israel para arreglar los “malos entendidos” y se encontraba ya en Nueva York. Echeverría explicó repetidamente el motivo de su presencia en la ciudad estadounidense: Rabasa estaba en la ONU para manejar personalmente los votos que se acercaban, "para asegurarse que ninguna acción de nuestra parte pueda parecer ser antisionista”. 223

Sin embargo, y a pesar de la presencia en Nueva York del canciller Rabasa, las cosas no salieron bien con el voto de Naciones Unidas el 15 de diciembre. Como resultado de ello, tal y como se ha expuesto en estas páginas, el boicot, que parecía estar a punto de terminar, fue ratificado.

El 16 de diciembre, Rabasa regresó a México. Antes de bajar del avión, subió a éste el subsecretario de Relaciones Exteriores, José Gallástegui, quien le traía instrucciones del presidente. Echeverría quería que en la conferencia de prensa que dictaría al descender del avión, leyera el texto que el

\footnotetext{
221 Rabasa, Canciller de México, p. 31.

222 Riding, Distant Neighbors, p. 348.

223 YUA-IM, c. 15, carp. 4, “Transcript Mexico Meeting...”, 12 dic. 1975, parte 5 , pp. 2,5 .
} 
presidente ya le había enviado a Nueva York. Debía, además, añadir lo escrito en una tarjeta que traía consigo el subsecretario. Textualmente, ésta decía, entre otras cosas: “Tengo entendido que ha habido aquí algunas afirmaciones de un grupo de desorientados. No pido perdón, ni la política exterior de México pide perdón. El voto de México fue correcto", y terminaba afirmando, en contra del sentido común, que "tampoco ha habido contradicciones, sino una gran coherencia en medio de la complejidad del mundo en que vivimos". 224

Rabasa decidió no leer esa nota, y tampoco el texto que se le había enviado a Nueva York; es más, ni siquiera se basó en él para su declaración. ${ }^{225}$ Antes de mostrar lo que Rabasa eligió decir, es conveniente presentar la situación que enfrentó a su llegada.

Cuando el secretario estaba todavía en Nueva York, se decía que "Rabasa había excedido su autoridad con los comentarios que había hecho en Israel”. De hecho así lo dijo un subsecretario de Relaciones Exteriores de México a Maass, el presidente del AJc. ${ }^{226}$

En México, las diversas reacciones que tuvieron las declaraciones de Rabasa habían sido viscerales. Entre otros, Samuel del Villar, columnista de Excelsior, dijo que era "intolerable" que un secretario de Relaciones Exteriores adoptara esa postura pública. Escribió: "Estos actos son sin paralelo y

${ }_{224}$ Rabasa, Canciller de México, pp. 153-154.

${ }^{225}$ Rabasa, Canciller de México, p. 154. Desafortunadamente no sé qué decía el texto que no leyó.

226 Richard Maass, "Observations on Meetings...”, Foreign Affairs Department, c. \# 4, Carp. Zionism Resolution, Reaction-Boycott, AJC, p. 2. 
degradan nuestra política exterior a los niveles más bajos de nuestra historia". ${ }^{227}$

El texto que Echeverría le había hecho llegar a Rabasa tenía la intención de responder a las críticas a la política exterior mexicana, pero Rabasa decidió no declamar lo que le ordenaba Echeverría. En sus memorias escribió su sentir: "Sean las que fueren las consecuencias, yo tenía que asumir, como lo hice, plena responsabilidad de mis actos y dar las explicaciones que estimare pertinentes". ${ }^{228}$

El punto más importante en el que difiere el texto leído por Rabasa de aquel que le había mandado el presidente fue la tercera oración, que decía: "El voto de México fue correcto”. En esta ocasión, Rabasa se rehusó a declararlo públicamente. Al mismo tiempo, Rabasa intentó defender la postura de que la política exterior mexicana sí era coherente. Aun en contra de la lógica, alegó que el voto del 10 de noviembre a favor del sionismo como una forma de racismo no había sido modificado en su viaje a Israel, y afirmó que "en nada se mermó la dignidad de México [...] ni pedí perdón”. 229

Sin embargo, los periodistas no aceptaron el argumento de que el viaje a Israel sólo había contenido aclaraciones y no había implicado un cambio de postura, e insistieron sin tregua una y otra vez en el significado más obvio de la expresión utilizada de forgiven and forgotten. ${ }^{230}$

Hacia el fin de la reunión con la prensa, se le preguntó: "En las últimas horas, señor, había el rumor de que usted

${ }^{227}$ Samuel del Villar, “Acto sin paralelo. La política exterior pide perdón”, Excelsior (16 dic. 1975).

228 Rabasa, Canciller de México, p. 154.

229 Rabasa, Canciller de México, pp. 148, 156-157.

230 Rabasa, Canciller de México, pp. 157-159. 
podría presentar su renuncia”, a lo que Rabasa respondió: "No, no estoy pensando en renunciar". Aun así, años después Rabasa escribió que al terminar la conferencia de prensa, se dio cuenta de que su "situación como secretario de Relaciones Exteriores era ya insostenible". ${ }^{231}$

Ésta no era la primera ocasión en que el canciller consideraba la posibilidad de renunciar al cargo. Sabemos que Rabasa lo pensó por lo menos en dos momentos anteriores. La primera vez fue a los escasos diez meses de haber comenzado su gestión. Se debió a que Echeverría afirmó en la ONU que apoyaba la inclusión de la República Popular China y la expulsión de Taiwán, y sin embargo, el día de la votación en la ONU, Echeverría mandó instrucciones a la delegación mexicana que contradecían, en el fondo, la posición de su discurso. "Las instrucciones presidenciales causaron desazón en la delegación mexicana, encabezada por mí [...]. Es la primera vez que pensé en renunciar."232

Y sin embargo no lo hizo.

La segunda ocasión fue en enero de 1975. Esa vez, Rabasa sí presentó su renuncia a Echeverría. Según cuenta Rabasa, se debió a "algunas indebidas intromisiones" que habían hecho en su área otros funcionarios del gobierno. Un diplomático de la época recuerda que en el área internacional Echeverría se asesoraba con Porfirio Muñoz Ledo y Emilio Pacheco. "Ellos se metían de lleno en la cuestión internacional y no tomaban en cuenta a la cancillería, Rabasa se sentía marginado. ${ }^{233}$ En ese entonces, Echeverría no

${ }^{231}$ Rabasa, Canciller de México, pp. 164-166.

232 Rabasa, Canciller de México, pp. 50 y 53.

${ }^{233}$ Ariela Katz Gugenheim. Correo electrónico de Walter Astié-Burgos, 13 mar. 2014. 
aceptó la renuncia y Rabasa permaneció al frente de la Secretaría. $^{234}$

En diciembre de 1975, el comportamiento del le hizo ver que no había otra salida. En los días que siguieron a la conferencia de prensa, Rabasa tuvo conversaciones telefónicas breves y tensas con Echeverría, que le confirmaron sus sospechas. Rabasa lo atribuyó a la interpretación "torcida y equivocada" que se había dado a sus palabras acerca del "borrón y cuenta nueva" y a su desacato para "declarar pública y expresamente que el voto sobre el sionismo había sido acertado", aun cuando Rabasa siempre votó de acuerdo a las "órdenes presidenciales". Rabasa consideró que se había producido "un deterioro irreparable en las relaciones" con el primer mandatario. ${ }^{235}$

El 29 de diciembre, 13 días después de haber regresado a México, finalmente Echeverría citó a Rabasa en Los Pinos. Cuando entró al salón donde se encontraba el presidente, éste lo recibió diciéndole: "Ahora sí le acepto la renuncia”. Rabasa ya llevaba el documento firmado. Escribió que a Echeverría "seguramente le sorprendió que [...] le hiciera entrega del mismo en el acto". ${ }^{236}$

Aunque la explicación oficial fue que renunciaba para entrar a la "política activa", los periódicos publicaron que obedecía al problema del viaje a Israel. ${ }^{237}$ Algunos incluso

\footnotetext{
234 Rabasa, Canciller de México, pp. 167-168.

235 Rabasa, Canciller de México, p. 166.

236 Rabasa, Canciller de México, p. 167.

237 Por ejemplo James Nelson Goodsell, “Anti-Zionist vote in un draws reprisals by private US groups. Jewish boycott cuts deeply into Mexican tourism”, The Christian Science Monitor (30 dic. 1975), p. 5 y Los Angeles Times.
} 
escribieron que cuando Rabasa regresó de ese país, había sido ridiculizado por la prensa mexicana. ${ }^{238}$

La noticia de la renuncia sorprendió incluso al embajador de Estados Unidos. ${ }^{239}$ Jova hizo saber en su informe que la prensa mostraba gran escepticismo frente a las razones que se difundieron sobre la renuncia. Esto se sumaba al hecho de que Rabasa mismo no lo hubiera explicado de manera clara y precisa. Jova sostenía que los ataques a Rabasa eran inmerecidos, criticó las "impulsivas iniciativas del presidente, en las cuales Rabasa no jugaba un papel de consejero, sino que tenía tan sólo la tarea de implementar las directivas presidenciales con lo mejor de sus habilidades". El problema por la votación acerca del sionismo le parecía a Jova sólo uno más de varios casos similares, y citó como ejemplos las acciones del gobierno frente al caso de España en la ONU y el flip-flop del gobierno respecto a Belice. ${ }^{240}$

Jova presentó un análisis cuya conclusión comparto: siendo que con anterioridad Rabasa "implementó fielmente políticas que seguramente consideraba dudosas”, el motivo de su renuncia no podía ser que ya no quería continuar impulsando iniciativas con las que no estaba de acuerdo.

El embajador pensaba que posiblemente Echeverría había tomado la decisión de manera personal. Agregó que su sucesor, Alfonso García Robles, había demostrado más afinidad

238 "Rabasa Resigns in Mexico", The Washington Post (30 dic. 1975), A, p. 8.

239 WiKI, ID: 1975STATE304175_b, Jova to Secretary of State, "Foreign Secretary Rabasa Resigns”, 30 dic. 1975.

240 NSA, Cable, MEXICO 11419, Jova to Secretary of State Washington. Immediate, Confidential, "García Robles replaces Rabasa as Foreign Secretary”, 30 dic. 1975, p. 3. 
con la política presidencial que Rabasa, a pesar de la actuación siempre fiel de este último.

Hubo también quienes atribuyeron la partida de Rabasa a la tendencia mexicana de acercarse al Tercer Mundo y alejarse de Estados Unidos. Esta inclinación había sido parcialmente responsable, en primera instancia, del voto de México el 10 de noviembre en la onu. Según esta interpretación, Rabasa no encajaba en esta concepción y por eso Echeverría lo había dejado ir. ${ }^{241}$

En efecto, Kissinger envió un cable muy cálido a Rabasa y pidió a Jova que se lo entregara personalmente. En éste le expresó su “sorpresa y tristeza” al oír de su renuncia. Le dijo que se había "beneficiado mucho de sus frecuentes reuniones”, afirmó que extrañaría su "tenacidad diplomática y sabio consejo”, y se despidió afirmando que siempre lo consideraría un “amigo cercano”. ${ }^{242}$

A continuación, quisiera proponer otra explicación de la partida de Rabasa de la Secretaría de Relaciones Exteriores. Echeverría no le permitía al canciller ser un consejero efectivo en materia internacional, lo había convertido en un ejecutor de los actos que aquel como presidente decidía, y que muchas veces formaban políticas incongruentes y contradictorias con las que el secretario no se identificaba. No obstante, Rabasa nunca cedió su cargo por ello.

241 “Mexico's Foreign Policy Trend Toward Third World Nations Seen As Reason for Rabasa's Resignation”, Jewish Telegraphic Agency (31 dic. 1975).

242 WiKI, ID: 1976MEXICO00034_b, Jova to Secretary of State "Messages On Rabasa’s Resignation And Garcia Robles’ Appointment”, 6 ene. 1976. 
Lo que cambió fue la voluntad de Echeverría, que en esta ocasión no quiso mantener al canciller Rabasa formando parte de su gabinete. ¿Por qué?

Ciertamente el incidente del "perdonado y olvidado" debió haber molestado a Echeverría. Es cierto, efectivamente, que la desafortunada expresión fue muy reprochada. Sin embargo, de haberlo querido, Echeverría pudo haberlo protegido de la crítica.

No cabe duda de que el desacato de Rabasa, quien se rehusó a declarar públicamente a su regreso de Israel que "el voto de México había sido correcto", enfureció al primer mandatario.

Propongo que hubo algo más.

A lo largo de este episodio de la historia nacional, desde el voto de la Resolución 3379, Echeverría se había enfrentado con la dificultad de satisfacer simultáneamente a dos tendencias opuestas: al bloque árabe soviético y al bloque integrado por los judíos e Israel. Sin embargo, a pesar de sus esfuerzos, no lo había logrado.

Cuando México votó afirmativamente el 10 de noviembre, el sector árabe estuvo muy al tanto y expresó su agradecimiento al presidente. ${ }^{243}$ Por su parte, el bloque judío reaccionó haciendo el boicot que hemos estudiado en estas páginas.

Cuando se emitieron los votos del 15 de diciembre, parece ser que Echeverría consideró que ya había hecho suficiente por el grupo judío: había desayunado con los judíos

243 Véase por ejemplo el documento en AHSRE, SRE SPR-824-3 y la lista de documentos de L-2265 NC Sardinero, VIII/411.11 (XXX) (06)/68 Primera y Segunda Parte, donde se menciona el agradecimiento expresado por el representante de la OLP en Egipto y el ministro de Asuntos Extranjeros de la República Árabe de Egipto, ambos en 1976. 
mexicanos, enviado a Rabasa a Israel y se había reunido en una comida con la delegación de judíos estadounidenses. Así que decidió mantener la postura adoptada en noviembre, a favor del bloque árabe soviético, y obligó a la cancillería a hacer una aclaración que todos sabían era insuficiente, para no poner en riesgo la complacencia del sector árabe soviético.

Su estrategia condujo a la ratificación del boicot.

Cuando Miguel Alemán le transmitió al presidente el mensaje de los líderes judíos de Estados Unidos, que pedían la confirmación de su compromiso y el despido del responsable del voto antisionista del 15 de diciembre, Echeverría creyó haber encontrado una salida a su dilema: darles la cabeza del secretario. Con ello, no comprometía su relación con el grupo árabe, pues había votado con ellos en la onU, pero apaciguaba a los judíos. El percance a raíz de las declaraciones de Rabasa en Israel le dio a Echeverría la oportunidad de sacrificar al canciller al tiempo que él se proyectaba como gran defensor del orgullo nacional.

Por ello, en lugar de reducir el impacto del forgiven and forgotten, Echeverría lo aumentó y lo capitalizó a su favor. Incluso al día siguiente de la renuncia de Rabasa, el presidente compareció ante el Congreso para la clausura de sesiones, acto al que los presidentes nunca antes habían acudido, y ahí declaró en un discurso improvisado que "cualquier mexicano preferiría morir antes que pedir perdón y, en primer lugar, el presidente de la República”, ${ }^{244}$ ante lo cual, el Congreso mexicano lo ovacionó de pie. ${ }^{245}$

244 Jorge Carpizo, "México, Poder Ejecutivo”, El Día (31 dic. 1975).

245 “Mexican Vote”, The Washington Post (1ํㅡㄹ ene. 1976), sec. A, p. 24. 
Tras esta declaración, para la opinión pública nacional e internacional, el motivo obvio de que Echeverría hubiese aceptado la renuncia de Rabasa estaba vinculado a que éste hubiera pedido perdón en Israel. ${ }^{246}$ Sólo unos pocos entendieron que el propósito principal era detener el boicot. $^{247}$

Por su parte, Rabasa siempre insistió en que él no fue el "chivo expiatorio" de un error o incongruencia del presidente, porque "el que trabaja para un sistema presidencialista como el nuestro, conoce su destino". ${ }^{248}$

\section{EL CESE DEL BOICOT}

Después de la ratificación del boicot, conjuntamente con el despido de Rabasa, comenzó un cambio en la postura pública de México.

En una reunión de la Organización de las Naciones Unidas para la Educación, la Ciencia y la Cultura (UnEsco) en París, México se rehusó a endosar otra resolución que incluía referencias a la resolución del 10 de noviembre que equiparaba al sionismo con el racismo. De igual forma, en una junta del International Civil Aviation Organization en Montreal, México se abstuvo en una resolución que atacaba al sionismo. ${ }^{249}$

\footnotetext{
246 Jewish Chronicle y otros.

247 "4 JDL Protesters Invade Consulate", Philadephia Daily Neres (30 dic. 1975).

248 Rabasa, Canciller de México, p. 166.

249 Benjamin Welles, "Travel Power: The Story behind the Mexico Boycott by...”, The New York Times (27 jun. 1976), sec. 10, Travel, p. 16.
} 
El Presidents' Conference ${ }^{250}$ y el gobierno israeli ${ }^{251}$ advirtieron claramente el cambio.

Además, los judíos mexicanos no le veían fin al boicot. Cuando la esperanza de que éste terminara el 15 de diciembre se esfumó, Sergio Nudelstejer llamó varias veces por teléfono a Morris Fine, director de Relaciones Exteriores del Ajc, y luego le envió una carta en la que le explicó que el boicot de Estados Unidos en contra de México había adoptado un aspecto muy peligroso, ya que había "abierto las puertas a una reacción local antisemita, antijudía y antiestadounidense en la opinión pública". Expresó su "insistencia y la determinación de todos los judíos mexicanos de que el boicot debe detenerse. ${ }^{252}$

En los primeros meses de 1976, la delegación que había viajado a México para reunirse con Echeverría presentó un reporte al Presidents' Conference. En él se hizo un recuento de lo sucedido: el viaje a México, la reunión con Echeverría y la abstención de México en el voto en la unEsco y en la Organización Internacional de Aviación Civil. Cabe destacar que el informe minimizó los votos negativos del 15 de diciembre.

En lugar de ello, se señaló que México había sido el único de los 72 países que aprobaron la resolución del 10 de

250 YUA-IM, c. 15, carp. 7, "Report for the Year Ending March 31, 1976", "V. The trouble with Mexico", p. 34.

251 NSA, Cable, Tel Av 08073, AMEmbassy Tel Aviv to Secretary of State Washington, "Cabinet communiqué on Mexican-Israeli relations", 22 dic. 1975, p. 1.

252 AJC, Collection: Foreign Affairs Department, c. \# 33, carp. Mexico 1975-1976, Zionism Resolution, Reaction-Boycott, Sergio Nudelstejer a Morris Fine, "Boycott of U.S.A. against Mexico", 22 dic., p. 1. 
noviembre, que tomó la iniciativa para restablecer las buenas relaciones entre México y Estados Unidos. Se aplaudió a Echeverría por "la franqueza" de sus declaraciones y por las acciones que su gobierno emprendió después del encuentro y se afirmó la creencia de que Echeverría “de ahora en adelante, enfatizará los aspectos positivos del sionismo". ${ }^{253}$ Los líderes judíos expresaron su confianza en que se estaban produciendo cambios en la manera de actuar de México y mejorías en su relación con Israel. ${ }^{254}$

Las organizaciones judías comenzaron a indagar la respuesta pública a un cambio de actitud. Escribieron a sus líderes locales señalando que, en vista del cambio favorable en la política mexicana, resultaba aconsejable reconsiderar las directrices del Presidents' Conference y de las demás organizaciones judías, que habían suspendido los viajes a México.

El presidente del B'nai B'rith subrayó en su carta que la postura que había tomado el B'nai B'rith al respecto contó en su momento con la aprobación abrumadora de sus miembros y de la comunidad judía en general. Alegó que los cambios importantes en la actitud del gobierno de México se debían a la acción conjunta de los judíos estadounidenses, y afirmó: "Nuestros esfuerzos se han justificado". Acto seguido, solicitó la opinión de sus integrantes para la reevaluación del boicot. ${ }^{255}$

253 YUA-IM, c. 15, carp. 5, "Report to the Conference of Presidents..." (14 ene. 1976), p. 3.

254 AJC, Collection: Foreign Affairs Department, c. \# 33, carp. Mexico 1975-1976, Zionism Resolution, Reaction-Boycott, Morris Fine to AJC, Area Directors, "Memorandum”, subject: Policy on Mexico, 22 ene. 1976.

255 AJC, Bertram Gold Carp.s, United Nations, Zionism, Mexico, 1976. 
El 26 de enero, el reporte presentado por un subcomité ad hoc repitió los argumentos que mostraban el giro de la postura de México, y concluyó que "efectivamente ha habido un cambio de rumbo en la actitud de México hacia el sionismo, Israel y el pueblo judío. Ya no nos enfrentamos ante un adversario, sino que hemos recuperado a un amigo. Por lo tanto, es nuestra recomendación que nuestras relaciones sean normalizadas". ${ }^{256}$

Llama la atención la gran calidez del texto, especialmente tomando en cuenta que se trata de un reporte interno.

Fue así que el 26 de enero el rabino Alexander M. Schindler, presidente entrante del Presidents' Conference, anunció en Nueva York la normalización de las relaciones entre los judíos de Estados Unidos y México. Sus declaraciones se difundieron en los periódicos estadounidenses y en la prensa mexicana.

Los principales periódicos de México aplaudieron la decisión de las instituciones judías de Estados Unidos y le dedicaron extensos espacios, celebrando que el boicot contra México hubiera terminado y señalando las buenas relaciones entre México e Israel, así como entre el gobierno de México y la comunidad judía local. ${ }^{25}$

Carta de David M. Blumberg a B'nai B'rith Leaders, 26 ene. 1976.

256 YUA-IM, c. 15, carp. 5, "Report to the Conference of Presidents of Major American Jewish Organizations by Committee on Mexican Relations, Seymour Graubard, Chairman”, 26 ene. 1976.

257 Algunos fueron: Armando Vargas, "Terminó el boicot judío a México en EU: A. M. Schindler”, Excelsior (28 ene. 1976), primera plana y p. 13. "Recuperamos un amigo, dice su presidente", Novedades (28 ene. 1976), primera plana y p. 10. "Recomienda normalizar relaciones entre los grupos judíos de EU y México”, Heraldo (28 ene. 1976). "México fue recuperado como amigo: judíos de EE.UU”, La Prensa (28 ene. 1976), y 
Sergio Nudelstejer escribió al American Jewish Committee lo complacido que estaba con esta medida: "Con estas declaraciones esperemos que el problema sea olvidado por completo". 258

Y sin embargo, debe señalarse que no todos estuvieron conformes con el proceso que se siguió para la cancelación del boicot. Algunas organizaciones sintieron que el anuncio fue prematuro y que el Presidents' Conference había sobrepasado sus facultades. ${ }^{259}$ Ello es una muestra de las tensiones internas entre las organizaciones judías estadounidenses que el boicot sacó a relucir y que ameritan ser estudiadas.

Incluso algunos de los estadounidenses no judíos que habían apoyado la medida del boicot se sorprendieron de que éste terminara tan poco después del voto de México el 15 de diciembre. ${ }^{260}$

Pocos días después, el 12 de febrero, el American Jewish Congress, el Union of American Hebrew Congregations y el National Council of Jewish Women, anunciaron

"Finalizó el boicot turístico a México" (28 ene. 1976), pp. 23 y 47. "Fin del boicot turístico a México", Ovaciones (28 ene. 1976), primera plana y p. 6, y "Vendrá a México el canciller de Israel en marzo" (28 ene. 1976). "Vayan a México, piden 38 organismos judíos”, El Sol de México (28 ene. 1976), primera plana y p. 12. "No hay adversario; recuperamos un amigo", El Universal (28 ene. 1976), primera plana y p. 11.

${ }^{258}$ AJC, Collection: Foreign Affairs Department, c. \# 33, carp. Mexico 1975-1976, Zionism Resolution, Reaction-Boycott, Sergio Nudelstejer a Morris Fine, 30 ene. 1976.

259 AJC, Bertram Gold Carps, United Nations, Zionism, Mexico, 1976, Carta de David M. Blumberg a Rabbi Alexander Schindler, Chairman de Conference of presidents of Major American Jewish Organizations, 29 ene. 1976.

260 Louis Halasz, “Acapulco's lure causes Jews to 'forget politics'”, Special to the Press, L.I. Press (5 feb. 1976). 
púbicamente que restablecerían los programas de viajes a México, en respuesta a la nueva posición mexicana respecto al sionismo. ${ }^{261}$

Esta vez, el presidente de México decidió ser más cuidadoso. El 3 de febrero, a los pocos días de la declaración pública de Schindler, Echeverría habló por teléfono con su embajador en Washington, José Juan de Olloqui y Labasti$\mathrm{da}$, instruyéndole para que organizara una cena con dirigentes judíos, con el fin de hacer oficial la normalización de las relaciones lo antes posible. ${ }^{262}$

La cena tuvo lugar la semana siguiente, en el Metropolitan Club de Nueva York, en un ambiente “cordialísimo”, con la presencia de Blumberg (presidente del B'nai B'rith), Schindler (presidente entrante del Presidents' Conference) y Miller (presidente saliente del Presidents' Conference). Ahí, Schindler le ofreció al embajador mexicano que tres organizaciones judías anunciarían la reanudación de viajes a México. ${ }^{263}$ De Olloqui reportó que el acuerdo dependía aún de que los miembros de las organizaciones aceptasen terminarlo, ${ }^{264}$ lo que ratifica la base popular del boicot.

261 "Three Jewish Groups Resume Travel Programs to Mexico", Jerwish Telegraphic Agency, New York, 12 feb. 1976.

${ }^{262}$ AHSRE, C/T 00878 Número 125, L-2265 NC Sardinero, VIII/411.11 (XXX) (06)/68 Primera Parte, TELEX Oficialía Mayor a Embamex Washington DC, 14 feb. 1976.

263 AHSRE, C/T 00878 Número 125, L-2265 NC Sardinero, VIII/411.11 (XXX) (06)/68 Primera Parte, TELEX Oficialía Mayor a Embamex Washington DC, 14 feb. 1976.

264 AHSRE, exp. 73-0/ No. 0729, VIII/411.11(XXX)(08)/68, Primera Parte, L-2262 Sardinero, Dirección General de Organismos Internacionales, José Juan de Olloqui a Alfonso García Robles, Washington, 24 feb. 1976. 
Una vez que se contó con la aprobación de todas las organizaciones, el boicot terminó oficialmente en febrero de 1976 y los grupos judíos retomaron sus viajes a México. Sin embargo, el proceso habría de ser más lento y ambivalente que el de la institución del boicot. ${ }^{265}$ En mayo de 1976, un sector de la prensa mexicana lo consideraba aún vigente, ${ }^{266} \mathrm{y}$ en octubre del mismo año todavía se sentía el impacto. ${ }^{267}$

\section{CONCLUSIONES}

Los cambios en política exterior efectuados por el presidente Luis Echeverría convirtieron al grupo de interés de judíos estadounidenses en un grupo de presión. En efecto, Echeverría despertó e impulsó al activismo de la comunidad judía de Estados Unidos. Este activismo transformó a la comunidad judía estadounidense en un agente de presión trasnacional que influyó exitosamente en el gobierno mexicano para que modificara su política exterior.

El propio Echeverría llegó a decir años más tarde a Emilio Rabasa: "Por lo que hace al asunto de Israel (o sea, el voto de México sobre el sionismo en la onU), el presidente de México se equivocó. Te autorizo, Emilio, para que lo publiques" ${ }^{268}$ También frente a Aída González, Echeverría admitió que no había entendido las implicaciones del voto en

265 Véase KATz, “La Resolución 3379”, cap. 4 pp. 150-163.

266 CDIJUM, Actas del Comité Central, Número de registro 6600, libro 13, acta núm. 9, 25 mayo 1976, f. 26.

267 Joy Cook, "Mexico Seeks Jewish Tourists”, New York Post (26 oct. 1976).

268 Esto sucedió el 28 de enero 2000, en un desayuno en casa de Rabasa. Rabasa, Canciller de México, p. 171. La información en paréntesis la agregó Rabasa mismo. 
la Conferencia del Año de la Mujer ni de la votación sionismo-racismo en la ONU. ${ }^{269}$

Cabe mencionar que el 16 de diciembre de 1991, la Resolución 3379 fue revocada en Naciones Unidas por la Asamblea General, único caso que se ha presentado en esta organización en que una determinación adoptada por la Asamblea General se rescinde. ${ }^{270}$

Quisiera señalar que la reconstrucción histórica del proceso mediante el cual se implementó el boicot, y de la manera en que éste se desarrolló, desmiente gran parte de lo que se creía conocer al respecto. Entre otros:

- Contrariamente a lo que afirmó un investigador, ${ }^{271}$ la idea del boicot no surgió dentro de la comunidad judía mexicana ni fue impulsada por ella. Al contrario, la comunidad judía local trató de detenerlo, pero se vio impotente para lograrlo.

- También Israel intentó detener el boicot, pero no contó con los medios para conseguirlo.

- El boicot tampoco fue resultado de la iniciativa de organizaciones judías estadounidenses. ${ }^{272}$ El boicot surgió de manera espontánea entre los judíos de Estados Unidos.

269 Ariela Katz Gugenheim. Entrevista vía telefónica con Walter AstiéBurgos, 28 nov. 2011.

${ }^{270}$ La revocación fue aprobada por un voto de 111 a 25, con 13 abstenciones. United Nations General Assembly Resolution 46/86 (16 dic. 1991). http://www.un.org/documents/ga/res/46/a46r086.htm acceso 8 de julio de 2014.

271 Véase Tawil, "Mexico's Foreign Policy towards Israel-Palestine”, pp. 1-35. http://cdn8.foreignpolicyjournal.com/wp-content/ uploads/2014/02/140225-Tawil-Mexico.pdf, acceso 7 de julio de 2014.

${ }^{272}$ La versión de que el boicot había sido iniciado por las organizaciones judías fue adoptada incluso por las mismas organizaciones, por lo que 
- No fueron los judíos mexicanos quienes consiguieron que sus homólogos estadounidenses fuesen recibidos por Echeverría, como lo asevera un estudio. ${ }^{273} \mathrm{La}$ iniciativa vino del gobierno mexicano.

- El viaje de Rabasa a Israel fue un reto que el canciller supo manejar exitosamente. Logró normalizar las relaciones con Israel y también consiguió que los judíos estadounidenses aceptaran reunirse con Echeverría. Rabasa no tuvo que dejar la secretaría porque "pidió perdón" en Israel. Echeverría decidió sacrificar a su canciller, con la intención de mostrar al grupo de presión judío estadounidense un viraje en sus relaciones exteriores, sin poner en riesgo su política de acercamiento al bloque árabe-soviético.

- El despliegue de poder por parte de la comunidad judía de Estados Unidos irradió fuerza a la comunidad judía de México frente a su gobierno. Los judíos de México llevaban tres meses solicitando una entrevista con Echeverría, sin haber conseguido ni siquiera una respuesta formal. Fue el boicot turístico el que los volvió de pronto relevantes para el presidente.

Mi propósito ha sido que esta investigación aporte respuestas a diversas cuestiones, y me satisface saber que provoca a su vez numerosas preguntas que será muy interesante elucidar. Entre ellas, cabe preguntarnos si la comunidad judía mexicana efectivamente resultó robustecida con este episodio, y cuáles fueron los alcances y los límites de este fortalecimiento.

no sorprende que sea dada por hecho por los investigadores. Entre otros, véase Magaña, “México ante el conflicto árabe-israelí”, p. 167.

273 Bokser Liwerant, “Fuentes”, p. 334. 


\section{SigLAS y REFERENCIAS}

AHSRE Archivo Histórico "Genaro Estrada" de la Secretaría de Relaciones Exteriores de México, Ciudad de México, México.

AJC Archivos de The American Jewish Committee, Institute of Human Relations, Blaustein Library, Nueva York, E.U.

AJCA American Jewish Congress Archives, Center for Jewish History, Nueva York, E.U.

CDIJUM Archivo del Centro de Documentación e Investigación Judío de México, Ciudad de México, México.

HA Hadassah Archives, The American Jewish Historical Society, Center for Jewish History, Nueva York, E.U.

ISA Israel State Archives, Jerusalem, Israel.

NSA The National Security Archive, The George Washington University, Washington D.C., E.U.

UNAR United Nations, Archives and Records Management Section, https://archives.un.org

Wiki Wikileaks, Public Library of US Diplomacy, https:// wikileaks.org/

YUA-IM Yeshiva University Archives, Israel Miller Papers, Nueva York, E.U.

Beilin, Yossi

His Brother's Keeper. Israel and Diaspora Jewry in the Twenty-first Century, Nueva York, Schocken Books, 2000.

BOKSER Liwerant, Judit

"Fuentes de legitimación de la presencia judía en México: el voto positivo de México a la ecuación sionismo=racismo y su impacto sobre la comunidad judía", en Judaica Latinoamericana. Estudios Histórico-Sociales III, Jerusalén, Editorial Universitaria Magnes, Universidad Hebrea, AmILAT, 1997, pp. 319-349.

Cimet, Adina

"Incomplete Allowance: Jews as a Minority in Mexico", en E.I.A.L., 8: 2 (jul.-dic. 1997). 


\section{Compilación}

Compilación seleccionada del marco jurídico nacional e internacional de las mujeres/Secretaría de Relaciones Exteriores, México, Secretaría de Relaciones Exteriores, UnIfEM, PNUd, 2008, t. III, pp. 11-17.

Gleizer, Daniela

El exilio incómodo. México y los refugiados judíos. 1933-1945, México, El Colegio de México, Universidad Autónoma Metropolitana-Cuajimalpa, 2011.

Herzog, Chaim

Living History. A Memoir, Nueva York, Pantheon Books, 1996.

Katz Kenner, Ariela

"La Resolución 3379 de la Asamblea General de la onu en 1975, el voto de México y el boicot turístico que le siguió”, tesis de doctorado en historia, México, Universidad Iberoamericana, 2014.

Magaña Duplancher, Arturo

“México ante el conflicto árabe-israelí: 1932-1976”, tesis de licenciatura en Relaciones Internacionales, México, El Colegio de México, 2006.

MANor, Yohanan

To Right a Wrong. The revocation of the UN General Assembly Resolution 3379 Defaming Zionism, Nueva York, Shengold Publishers, 1996.

Moynihan, Daniel Patrick y Suzanne Weaver

A Dangerous Place, Boston, Little, Brown and Company (An Atlantic Monthly Press Book), 1978.

Rabasa, Emilio O.

Canciller de México. Mis memorias como secretario de Relaciones Exteriores 1970-1975, México, Secretaría de Relaciones Exteriores, Miguel Ángel Porrúa, 2010. 
Raffel, Martin J.

"History of Israel Advocacy", en Jewish Polity and American Civil Society. Communal Agencies and Religious Movements in the American Public Sphere, Lanham, MD, Rowman \& Littlefield Publishers, 2002, pp. 103-177.

Riding, Alan

Distant Neighbors: a portrait of the Mexicans, Nueva York, Alfred A. Knopff, 1985.

Schoenberg, Harris O.

The World Conference against Racism: The Adoption and Repeal of the $Z=R$ Resolution and the Implications for UN Reform, Wayne, New Jersey, The Center for U.N. Reform Education, 2001.

STERn, Kenneth S.

Anti-Zionism: The Sophisticated Anti-Semitism, Nueva York, American Jewish Committee, Institute of Human Relations, septiembre de 1990, 38 pp.

"The Enlightened World Reacts", en Israel Digest, xvin: 24 (21 nov. 1975), pp. 3-4.

TAw IL, Marta

"Mexico's Foreign Policy towards Israel-Palestine and Iran (2006-2012)", en Foreingn Politicy Journal (25 feb. 2014).

Troy, Gil

Moyniban's Moment: America's Fight against Zionism as Racism, Nueva York, Oxford University Press, 2013. 